\title{
A BRUTA ANIMALIA LATIN FORDÍTÁSAI: ANTONIO CASSARINO ÉS LAMPUGNINO BIRAGO*
}

\begin{abstract}
Plutarchos Bruta animalia ratione uti című eleven dialógusából három latin fordítás is készült a XV. század folyamán, melyek csak kéziratban maradtak fenn. Hogy a fordítások belső viszonyait felfedjük, a kézirati szövegek mélyreható elemzésére van szükség. Egy korábbi tanulmányunkban feldolgoztuk Giovanni Regio időben legkésőbbi fordítását (1488), kimutatva azokat a szálakat, amelyek elődje, a milánói Lampugnino Birago fordításához (1465-1470 körül) füzik. Most a szicíliai Antonio Cassarino legkorábban készült fordításának (1440-1445 körül) a vizsgálatát kívánjuk elvégezni párhuzamosan utódja, Lampugnino Birago negyed évszázaddal későbbi fordításával, hogy összehasonlítsuk módszerüket és stíluseszközeiket. A két fordító megközelítése között lényeges különbség figyelhető meg. Míg Cassarino a humanista fordításeszményt követve „értelem szerinti” (ad sententiam) fordításra törekszik, addig Birago inkább a „szó szerinti” (ad verbum) fordítás követelményének tesz eleget. A fordításelmélet általános kérdései mellett tárgyaljuk a latin fordítások kézirati hagyományának, görög forrásszövegének, valamint szóhasználatának problémáját.

Kulcsszavak: Plutarchos, Bruta animalia ratione uti, Antonio Cassarino, Lampugnino Birago, humanista latin fordítások, ad sententiam és ad verbum fordítás
\end{abstract}

Plutarchos Moralia címü gyüjteményében van néhány különleges darab, amely az állatok témájával foglalkozik. ${ }^{1}$ Helyesebben nem is az állatok képezik ezeknek a müveknek a tárgyát, hanem a kor szellemének megfelelően maga az ember, aki az erényre törekszik, és aki ennek a törekvésnek a során az állatok természet szerinti életmódjában keres útmutatást. Ezeket a műveket a témaválasztásuk miatt már az ókorban is kedvelték, később pedig, amikor a humanizmus Európában ismét felfedezte Plutarchos irodalmi örökségét, lassanként beszivárogtak a müvelt köztudatba, és kifejtették hatásukat a későbbi évszázadokban.

Az a mü, amely az említett csoportból a legkorábban ismertté vált a humanista latin fordítások révén, egy szellemes kis dialógus, a Bruta animalia ratione uti (a továbbiakban Bruta animalia). Nem kevesebb mint három fordítása készült el a XV. század folyamán, és jelentős utóélettel büszkélkedhet, hiszen olyan személyek népszerüsítették, mint Rotterdami Erasmus vagy Niccolò Machiavelli. ${ }^{2}$ Korábbi tanulmányunkban a három fordítás közül részletesen foglalkoztunk a legkésőbbivel, amelyet az ifjú Giovanni Regio 1488-as padovai keltezéssel Niccolò Francónak, Treviso püspökének ajánlott, ${ }^{3}$ két évtizeddel később pedig testvérbátyja, Raffaele Regio adott ki posztumusz nyomtatás-

\footnotetext{
A jelen tanulmány a K 112283 számú OTKA-projekt keretében készült.

${ }^{1}$ Cím szerint a következők: De esu carnium (993a-999b), Bruta animalia ratione uti (985d-992e), De sollertia animalium (959a-985c) és De amore prolis (493a-497e).

2 A Bruta animalia tartalmának és humanista fogadtatásának ismertetéséhez lásd Gaál B.: A Bruta animalia latin fordításai: Giovanni és Raffaele Regio. AntTan 62 (2018) 211 sk.

3 Biblioteca Universitaria di Padova Ms. 958.
} 
ban Velencében, miután jelentős változtatásokat eszközölt a kézirati szövegen. ${ }^{4}$ Már az ottani fejtegetésünkben is ki kellett térnünk a Bruta animalia két korábbi latin fordítására, amelyek szintén csak kéziratban maradtak fenn. Az egyiket a szicíliai Antonio Cassarino készítette 1440-1445 körül, a másikat pedig a milánói Lampugnino Birago 1465-1470 körül. A jelen tanulmányban ennek a két fordításnak az ismertetését tűzzük ki célul, annál is inkább, mivel előzőleg számos arra utaló jelet találtunk, hogy Giovanni Regio komolyan merített elődje, Lampugnino Birago fordításából. Joggal vetődik fel tehát a kérdés, hogy vajon Lampugnino Birago és Antonio Cassarino fordítását milyen viszony füzte egymáshoz. Ennek a két személynek amúgy is jelentős része volt a humanista Moralia-fordítások előmozdításában. Mindketten arra vállalkoztak, a maguk korában egyedülállóan, hogy a gyűjteménynek egyszerre több darabját is lefordítsák, ${ }^{5}$ amivel a kezdeti lépéseket tették meg egy majdan elkészülő teljes Moralia-fordításhoz. A két fordító megközelítési módja és az általuk követett fordítási gyakorlat azonban lényegesen eltér egymástól, és jól tükrözi a saját korukban a fordítás kérdésében uralkodó ellentétes nézeteket (ad verbum és ad sententiam fordítás).

Antonio Cassarino Notóban született a XIV. század végén. ${ }^{6}$ Nem tudjuk, hogy melyik neves itáliai egyetemen tanult, ám a döntő fordulatot életében a csaknem fél évtizedes Konstantinápolyban való tartózkodás hozta meg az 1430-as évek második felében. Több kortársához hasonlóan a görög nyelv biztos ismeretét itt sajátította el. Érdeklődése is ebben az időben alakulhatott ki Platón és Plutarchos iránt, akiknek a műveit előszeretettel fordította a későbbiekben. Nem utolsósorban felfigyelt a dialógus műfajának arra a sajátosságára, hogy képes élvezetesen tanítani, ezért eshetett a választása Platón és Plutarchos dialógusaira. A Septem sapientium convivium lefordításának ötletét egyik levele alapján egy olyan alkalom szülte, amikor félve hívták meg egy lakomára, nem tudván, hogy szabad-e egy filozófusnak conviviumon részt vennie. Cassarino kifejtette Platón, Plutarchos és mások tekintélyéhez folyamodva, hogy semmi sincs, ami jobban illene egy filozófushoz, mint a convivium. Ezt bizonyítják azok a művek, amelyeket ezek a jeles ókori szerzők maguk mögött hagytak. Ugyanebben a levélben találjuk azokat a gyakran idézett szavakat is, amelyekkel Cassarino kifejezésre juttatta, hogy mennyire kedveli Plutarchost. ${ }^{7}$

${ }^{4}$ Plutarchi Dialogus, in quo animalia bruta ratione uti monstrantur, Ioanne Regio interprete. Impressum Venetiis opere et impensa Georgii de Rusconibus, MDVIII, die 2 octobris, [76 ${ }^{\mathrm{a}}-83^{\mathrm{a}}$ ].

${ }^{5}$ Antonio Cassarino szám szerint kilenc művet (De laude ipsius, Quomodo adulator ab amico internoscatur, Bruta animalia ratione uti, De capienda ex inimicis utilitate, De cohibenda ira, Septem sapientium convivium, Regum et imperatorum apophthegmata, Apophthegmata Laconica, De cupiditate divitiarum), Lampugnino Birago pedig öt müvet (De laude ipsius, Quomodo adulator ab amico internoscatur, De cohibenda ira, Bruta animalia ratione uti, Apophthegmata Laconica) fordított le.

${ }^{6}$ Részletes életrajzi adataihoz lásd G. Resta: Antonio Cassarino e le sue traduzioni da Plutarco e Platone. IMU 2 (1959) 207 skk.; uö: Cassarino, Antonio. DBI 21 (1978) 442 skk.

7 Resta: i. m. (6. jegyz. [1959]) 272: Plutarchus, gravissimus philosophus, quem a me magnopere adamari vos scitis... 
Amikor Konstantinápolyból visszatért, rövid időn belül Genovában kapott tanári állást állami fizetésért. Változó anyagi körülmények között élt az ezt követő bő fél évtizedben, mivel a fizetését többször is csökkentették, és nyilvános panasszal kellett élnie a vezetők felé, hogy elégtételt kapjon. Ugyanakkor ezek voltak azok a termékeny évek is, amikor Platón és Plutarchos műveit átültette latinra, vagy legalábbis végső formába öntötte és ajánlásokkal látta el a kész fordításait. Cassarino kijelentéseiből arra következtethetünk, hogy szándékában állt Platón és Plutarchos összes művét lefordítani. ${ }^{8}$ Valójában két pseudo-platóni dialógus, ${ }^{9}$ továbbá a Respublica fordítása született meg; a plutarchosi Moralia-darabok közül pedig a korábban már felsorolt kilenc mű. A Respublica fordítását honfitársa és barátja, Antonio Panormita javaslatára készítette el, aki Cassarinót Aragóniai Alfonz nápolyi udvarába kívánta átköltöztetni, ám ehhez egy mutatósabb fordítás és ajánlás benyújtására volt szükség. Sajnálatosan Genovában 1447-ben lázadás tört ki, melynek során Cassarino házába is betörtek, aki az ablakon keresztül próbált a szomszédos ház ablakába átmenekülni, de az ugrást elvétette és szörnyethalt. Halála után Panormita vette gondozásba a Platón- és Plutarchos-fordításokat. Az általa összeállított kódexek szolgáltatják máig a legbiztosabb kiindulópontot Cassarino fordításainak szövegéhez. ${ }^{10}$

Antonio Cassarino fordításai ugyan sem életében, sem halála után nem voltak túlzottan közismertek, a hatásukról mégis képet alkothatunk néhány nevesebb kortársának kedvező vagy kedvezőtlen ítéletéből. A fordítások ajánlásait többnyire genovai előkelőségeknek címezte, akiknek feltehetően hálával tartozott, ${ }^{11}$ más esetekben pedig személyes ismerőseinek vagy tanítványainak. ${ }^{12}$ Úgy tűnik, hogy nem törekedett a kapcsolatrendszerét befolyásosabb körökre kiterjeszteni. Ennek ellenére az egyik első Platón-fordítása eljutott Milánóba, Francesco Filelfo kezébe, aki rögtön tollat ragadott, és görög nyelvü levélben fejezte ki elragadtatását Cassarinónak az ékesszóló latin fordítás iránt. ${ }^{13}$ Filelfo úgy fogalmaz, hogy örömmel látta, mennyire „virágos stílusban” ültette át az eredeti szöveget latinra, ${ }^{14}$ amivel nemcsak müveltségéről, hanem szépérzékéről is tanúbizonyságot tett. Egyúttal a legforróbb barátságát ajánlotta neki, amivel nem tudjuk, hogy Cassarino valaha élt-e. Sőt, a sors úgy hozta, hogy néhány évvel később, amikor a plutarchosi Apophthegmata Laconica fordításán dolgozott, a tudomására jutott, hogy a mü párját, amelynek Regum et imperatorum apophthegmata a címe, már valaki lefordította latinra, bár azt nem tudta, hogy Filelfo volt a fordító. Miután alkalma nyílt belepillantani ebbe a fordításba, a véleménye lesújtó volt róla. Úgy ítélte, hogy a fordító,

8 Resta: i. m. (6. jegyz. [1959]) 227 és 251.

${ }^{9}$ Axiochus, vel De morte; Eryxias, vel De divitiis.

${ }_{10}$ Vat. lat. 3346 és Vat. lat. 3349.

11 Tommaso Fregoso dózse és unokaöccse, Antonio Fregoso (egy, illetve három mủvel); Andrea Bartolomeo Imperiali (két mủvel); Brancaleone Grillo (egy művel).

12 Giacomo Curlo (három művel); Stefano De Marinis (egy művel).

${ }^{13} \mathrm{Az}$ 1440-ben írott levél szövegéhez lásd É. Legrand: Cent-dix lettres grecques de François Filelfe. Paris 1892. 34 sk. (= 04.09 De Keyser).

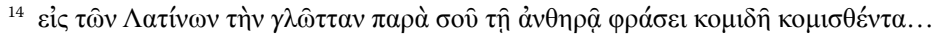


ha valamit tudott is latinul, a görögöt annyira rosszul vagy egyáltalán nem értette, hogy nemcsak az eredeti értelmet nem adta vissza, hanem az olvasót is teljesen magára hagyta minden értelmezési kísérlet nélkül. ${ }^{15}$ Így Cassarino feljogosítva érezhette magát arra, hogy ezt a mủvet is újrafordítsa. Később azonban valószínüleg megtudta, hogy ki volt a fordító, mivel a „nem csekély tekintélyű férfiú” szavakkal utal rá, ügyelve arra is, hogy kerülje a nyílt gáncsoskodást. ${ }^{16}$

Nagyobb feszültséget váltott ki Cassarino az érintettekből a platóni Respublica újrafordításával. Tudvalevő, hogy ezt a fontos müvet még Manuél Chrysolóras fordította le görögből közös vállalkozásban Uberto Decembrióval az 1400-as évek elején. A fordítás nehézkesre sikerült, mivel Chrysolóras a latin stílusérzékben, Decembrio pedig a görög nyelvismeretben mutatott fogyatékosságokat. Ez lehetett az oka annak, hogy Pier Candido Decembrio, Uberto fia vállalta, hogy mintegy négy évtized múltán készít egy javított fordítást a műből. Azonban Pier Candido Decembrio fordítását is vádak érték, hogy túl sokat merített az apjától, akinek a szövegét csak átdolgozta. ${ }^{17}$ Ebben a légkörben fogott neki Cassarino az újrafordításnak. A fordításhoz írott elöszavában nem bánt kíméletesen elődeivel. Chrysolóras esetében a latin nyelvi jártasságot hiányolta, mintha elég volna a görög eredetit érteni, a két Decembrióról pedig megjegyezte, hogy nem a saját tollukkal ékeskedtek. Az egyik a tanítója, a másik az apja érdemeit tulajdonította a magáénak. Pier Candido Decembrio átdolgozásáról keményebb bírálatot is megfogalmazott. Azt írja, miközben Platónt díszesebb formába akarta öltöztetni, nemcsak fordítói kötelességének nem tett eleget, hanem úgy adta vissza, hogy mindenre hasonlít inkább, mint Platónra. Alig lehet belőle valami keveset érteni, azt is csak a sejtésünkre hagyatkozva. A szerénység leple mögé bújva Cassarino nem állítja, hogy képes azt a színaranyat visszaadni, amit Platón képvisel, ám mint mondja, elégedett lesz, ha nem sározza be, mint előtte többen. ${ }^{18}$

Pier Candido Decembrio csak egy évtizeddel Cassarino halála után értesült a Respublica újrafordításáról. Apja és saját nevében Apologia címen védőbeszédet adott ki, amely mára elveszett. Fogalmat alkothatunk viszont a tartalmáról néhány kódex megjegyzéséből, amelyekkel a két Decembrio fordítását kísérték. Az egyik szerint egy Antonio Cassarino nevü „szélhámos” megpróbálta cáfolni a két Decembrio fordítását szicíliai fecsegésével; a másikban pedig azt olvassuk, hogy Antonio Panormita bujtotta fel Cassarinót a mű újrafordítására, amely úgy sikerült, hogy egyaránt jól tükrözi a fordítójának arcátlanságát és a görög és latin nyelvekben való járatlanságát. ${ }^{19}$ Ami érdekesebb a mi szempontunkból, hogy egy levelezésből kiderül, Lampugnino Birago arról kérdezte

15 Resta: i. m. (6. jegyz. [1959]) 245.

16 Resta: i. m. (6. jegyz. [1959]) 246. Mentségül írhatta Cassarino a fordítás végére görögül azt a mondatot, amellyel tisztázni akarta, hogy a művet nem egyéb okból, mint gyakorlás céljából fordította le. Vat. lat.

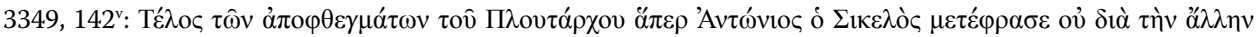

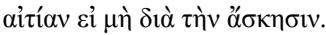

17 A kérdés bővebb tárgyalásához lásd Resta: i. m. (6. jegyz. [1959]) 254 skk.; J. Hankins: Plato in the Italian Renaissance. Vol. I. Leiden 1990. 105 skk.

18 Resta: i. m. (6. jegyz. [1959]) 261.

19 Resta: i. m. (6. jegyz. [1959]) 269, n. 2. 
Pier Candido Decembriót, akivel jó kapcsolatot ápolt, hogy milyen ember volt Antonio Cassarino. Ezzel a kérdéssel nyilván az elevenére tapintott. Decembrio kiönti keserüségét, amikor válaszában elmondja, Cassarino minden jónak az ellensége volt, aki állandóan azt leste, hol köthet bele mások munkájába és szerezhet érdemet ezzel, így szemelte ki a Respublica fordítását is, amely ragyogóan meg volt írva, ám úgy elcsúf ította, hogy csapnivalóbbat soha nem alkottak. ${ }^{20}$

A modern szaktudomány azonban nem osztja ezt a véleményt. Többen összevetették a fordítások részleteit, amiből világos, hogy a Chrysolóras-Decembrio-változathoz képest Cassarino fordítása összehasonlíthatatlanul jobb, tartalom és stílus szempontjából egyaránt korának legmagasabb színvonalán áll. ${ }^{21}$ Hasonló eredményre jutott a kutatás a plutarchosi De cohibenda ira újrafordításának kérdésében is ${ }^{22}$ Ennek a humanizmusban igen népszerű műnek a sorsa párhuzamos azzal, amit a Respublica befutott. Először a bizánci Simón Atumanos fordította le Avignonban az 1370-es évek elején. Ezt a görög eredetihez túlzottan ragaszkodó fordítást azután két évtizeddel később Coluccio Salutati igazította ki latin nyelvi szempontból anélkül, hogy a görög szöveget látta volna. Indokolt volt tehát Cassarino részéről csaknem fél évszázad múltán hozzányúlni a szöveghez azért, hogy végre méltó fordítás készüljön belőle. Egyébként elmondható, hogy a két említett példán kívül (Regum et imperatorum apophthegmata és De cohibenda ira) Cassarino választása olyan plutarchosi művekre esett, amelyeknek nem volt korábbi latin fordítása. Így például nem válogatta be a lefordítandó darabok sorába a Guarino Veronese által 1411-ben lefordított De liberis educandis című művet. A Moralia-művek egész sorának görögből való lefordítása minden előzmény nélkül már önmagában véve is tiszteletre méltó vállalkozás. ${ }^{23}$

Cassarino világosan megfogalmazta hitvallását a fordítással kapcsolatban. Miközben tisztában volt vele, hogy szemére vethetik, miért nem új művek létrehozásával, hanem régiek lefordításával tölti idejét, védelmére kelt ennek a gyakran lenézett foglalatosságnak. Cáfolva azt a nézetet, hogy a fordítás ne volna méltó a kor művelt emberéhez, határozottan kijelenti, ez a tanulmány segíti csak elő igazán a kultúra terjedését. Ahogy ugyanis a kereskedők azáltal, hogy beszállítják a városba a hiányzó árucikkeket a külföldi országokból, ahol ezekből bőséggel van, a gazdaság virágzásához járulnak hozzá, úgy a fordító is, aki elérhetővé teszi polgártársai számára a külföldi kulturális értékeket, a leghasznosabb tevékenységet végzi. Vajon az ókori rómaiak legjobbjai, mint Cicero

${ }^{20}$ Resta: i. m. (6. jegyz. [1959]) 269; Hankins: i. m. (17. jegyz.) 158, n. 107.

${ }^{21}$ Resta: i. m. (6. jegyz. [1959]) 263 skk.; Hankins: i. m. (17. jegyz.) 154 skk. és 422 skk.

${ }^{22}$ Resta: i. m. (6. jegyz. [1959]) 241 skk.

23 A Moralia egyes darabjainak humanista fordításához lásd C. Bevegni: Appunti sulle traduzioni latine dei Moralia di Plutarco nel Quattrocento. StudUmanistPiceni 14 (1994) 71 skk.; F. Stok: Le traduzioni latine dei Moralia di Plutarco. Fontes 1-2 (1998) 117 skk.; F. Becchi: Le traduzioni latine dei Moralia di Plutarco tra XIII e XVI secolo. In: Plutarco nelle traduzioni latine di età umanistica. Ed. P. V. Cacciatore. Napoli 2009. 9 skk.; uö: Humanist Latin Translations of the Moralia. In: Brill's Companion to the Reception of Plutarch. Eds. S. Xenophontos - K. Oikonomopoulou. Leiden 2019. 458 skk. 
vagy Plautus, nem görög művek fordításával gyarapították koruk ismereteit, amelyekre máig hagyatkozunk? ${ }^{24}$

Azonban óva int attól, hogy kellő szakértelem nélkül álljunk neki a fordításnak. A legrosszabb szolgálatot azok teszik az ügynek, akik a szöveg értelmével mit sem törődve mindent szóról szóra lefordítanak, elvétve nemcsak a jelentést, hanem a jóhangzás szabályait is. Ezzel elérik, hogy az olvasók a görögökről, akik a legékesszólóbbak voltak, azt hiszik, hogy nem tudták szépen kifejezni magukat. Pedig valójában a fordító bizonyul erre alkalmatlannak. Olykor annyira homályosan fordítanak, inkább a szavakat követve, mintsem az értelmet, hogy sem maguk nem képesek megragadni a lényeget, sem másoknak nem teszik ezt lehetővé. Vagyis aki fordításra szánja el magát, annak a nyelvi jártasságon és a jó stílusérzéken túl komoly hivatástudattal is rendelkeznie kell, hiszen a felelőssége nagy a kulturális értékek átadásában. Ezért Cassarino mindennél jobban becsüli azt a törekvést, hogy a fordítás adta nehézségekkel megbirkózva az ember átadja magát ennek a hivatásnak. ${ }^{25}$

Ezek a fordítás kérdésében megfogalmazott elvek jól illeszkednek a kor általános meggyőződésébe. Közismert, hogy a humanisták fordításeszménye a középkori „szóról szóra” (ad verbum) való fordítási módszerrel szemben az „értelem szerinti” (ad sententiam) fordítást határozta meg követendő célként. ${ }^{26} \mathrm{~A}$ felismerés nem volt új, hiszen már Cicero is hangot adott hasonló elveknek. ${ }^{27}$ Úgy vélte, hogy a fordítónak mintegy versenyre kell kelnie az eredeti szöveggel ahhoz, hogy méltón át tudja adni. Ez azt jelenti, hogy a fordítás során a gondolati tartalmak, illetve értelem (sententia) és az ennek kifejezésére szolgáló stíluseszközök (figura) átadása elsőbbséget kell hogy élvezzen a szavak puszta számával szemben, amelyeket nem darabra, hanem súlyra mérünk. Így lehetséges, hogy ami a görögben egy szó, az a latinban több szó legyen. Vagyis a fordítónak magának is latba kell vetnie a legjobb szónoki képességét ahhoz, hogy sikerrel át tudja adni a tartalom és forma egységét.

Az ékesszóló latin nyelvhasználat követelménye a humanista müveltségben maga után vonta a cicerói fordítási elvek újjáéledését. Ennek eredménye volt többek között, hogy Simón Atumanos vagy Manuél Chrysolóras nyersnek érzett Plutarchos-, illetve Platón-fordítását megpróbálták elegánsabb latin nyelvre átültetni, ahogy évtizedekkel

${ }^{24}$ Resta: i. m. (6. jegyz. [1959]) 259.

${ }^{25}$ Resta: i. m. (6. jegyz. [1959]) 259 sk.

${ }^{26}$ A fordítással kapcsolatos humanista elképzelésekről általában lásd $R$. Sabbadini: Del tradurre i classici antichi in Italia. A\&R 3 (1900) 201 skk.; L. Gualdo Rosa: Le traduzioni dal greco nella prima metà del' 400: alle radici del classicismo europeo. In: Hommages à Henry Bardon. Eds. M. Renard - P. Laurens. Bruxelles 1985. 177 skk.; M. Cortesi: La tecnica del tradurre presso gli umanisti. In: The Classical Tradition in the Middle Ages and the Renaissance. Eds. C. Leonardi - B. M. Olsen. Spoleto 1995. 143 skk.; uö: Vocazioni umanistiche e traduzione: nuove conquiste culturali. In: Miscellanea graecolatina III. Eds. S. Costa - F. Gallo. Roma 2015. 135 skk.; E. Berti: La traduzione umanistica. In: Tradurre dal greco in età umanistica. Metodi e strumenti. Ed. M. Cortesi. Firenze 2007. 3 skk.

27 Vö. Sabbadini: i. m. (26. jegyz.) 203 sk.; A. Den Haan: Giannozzo Manetti’s New Testament. Translation Theory and Practice in Fifteenth-Century Italy. Leiden 2016. 87 skk. 
korábban ez a szándék már megfogalmazódott Leonzio Pilato szó szerinti Homérosfordításaival kapcsolatban is. ${ }^{28}$ Némi időbe telt, amíg az „értelem szerinti” fordítás elve meg tudott gyökerezni a felfogásban. Így például Leonardo Bruni kezdetben még szívesebben tartotta volna meg a „szó szerinti” fordítást, ahol ez nem ütközött a jóhangzásba. Később azonban a Platón-, Plutarchos- és Aristotelés-fordításokban szerzett tapasztalata alapján határozottabban képviselte az „értelem szerinti” módszert, míg végül a keze alatt megszületett az első fordításelméleti mü, amelyet Jeromos óta írtak, a De interpretatione recta. ${ }^{29}$ Hogy csak egy szemléletes példát idézzünk, Bruni úgy fogta fel a platóni művek fordítását, hogy elképzelte, mi volna, ha maga Platón személyesen jelenne meg és mondaná tollba latinul a müvét, mintha az az anyanyelve volna. Marianne Pade erre a módszerre legutóbb a domesticating jelzőt alkalmazta, mivel a fordító úgyszólván a saját nyelvére „honosítja” az idegen szöveget. ${ }^{30}$ Hajlamos így értelmezni Bruni híres új transduco szóhasználatát is, amellyel a középkori transfero kifejezést cserélte fel, vagyis a fordítás hazai földbe való átültetést jelentene. ${ }^{31}$ Ennek az ellentéte a foreignizing fordítás, amikor a fordító a saját anyanyelvét „külföldiesíti”, mivel a sajátosságait a lefordítandó nyelvéhez igazítja, egyúttal idegen hatást keltve. A fordításnak ebben a fajtájában az idegen szavak eredeti „sajátosságának” (proprietas) a megőrzésén van a hangsúly.

Cassarino Moralia-darabok lefordítására irányuló tervébe, valamint a fordítással kapcsolatos néhány műhelytitkába bepillantást nyerhetünk a művek elé írott ajánlásaiból. Mindjárt az első lefordított mű ajánlásában azokról a müfajokról beszél, amelyek alkalmasak a bölcsesség közvetítésére. Ezek között foglal helyet az a müfaj, amelyet Plutarchos űzött a legmesteribben, aki az „erkölcsinek” (morales) nevezett írásaiban úgy gyűjtötte össze a régi költőktől és íróktól származó példákat, ahogy a méhek gyűjtik öszsze a virágokból a mézet. Mindent, amit mondtak vagy cselekedtek a múltban, felhasználta az erkölcsi jobbítás céljára. Plutarchos mủvei különösen azzal nyủgözték le Cassarinót, hogy páratlan műveltséggel íródtak, ezért méltónak találta őket a lefordításra. ${ }^{32}$

A fordítások ajánlásai megmutatják, hogy azok a változatok, amelyeket a címzetteknek elküldött, nem feltétlenül voltak azonosak a végleges szövegváltozatokkal. Több alkalommal kéri a megszólított személyeket, hogy csak akkor kezdjék el terjeszteni a fordítást, miután maguk is a jóváhagyásukat adták, vagy pedig átnézették egy arra alkalmas személlyel..$^{33}$ Megemlíti, hogy nem szívesen válna rágalmazók vagy túlérzékeny bírálók célpontjává a fordítás hiányosságai miatt. ${ }^{34}$ Nemegyszer önkritikusan beismeri,

${ }^{28}$ Vö. Gualdo Rosa: i. m. (26. jegyz.) 184 sk.; Den Haan: i. m. (27. jegyz.) 100 sk.

29 Vö. J. Hankins: Translation Practice in the Renaissance: The Case of Leonardo Bruni. In: Humanism and Platonism in the Italian Renaissance. I. Humanism. Roma 2003. 177 skk.; Den Haan: i. m. (27. jegyz.) 103 skk.

${ }^{30}$ M. Pade: Greek into Humanist Latin: Foreignizing vs. Domesticating Translation in the Italian Quattrocento. Renæssanceforum 14 (2018) 1 skk.

${ }^{31}$ Pade: i. m. (30. jegyz.) 9.

32 Resta: i. m. (6. jegyz. [1959]) 228.

33 Resta: i. m. (6. jegyz. [1959]) 228 sk. (De laude ipsius), 233 (Bruta animalia), 245 (Regum et imperatorum apophthegmata).

${ }^{34}$ Resta: i. m. (6. jegyz. [1959]) 230 (Quomodo adulator ab amico internoscatur), 237 (De cohibenda ira). 
hogy a görögből latinra való fordítás során megoldhatatlan nehézségekkel találta szembe magát, ezért figyelmezteti olvasóját, hogy bizonyos pontokon megütközhet. ${ }^{35}$ Máskor nem leplezi, hogy nem jutott ideje a szöveg utólagos kiigazítására, amely többé-kevésbé rögtönzött formában maradt, és talán nem elég ékesszóló. ${ }^{36}$ Sőt egy alkalommal kívánatosnak tartotta volna a fordítást ellenőrizni egy másik görög kódex segítségével is, amire végül nem került sor. ${ }^{37}$ Mindezekért a fogyatékosságokért azzal próbálja kárpótolni a címzettet, hogy kifejezi reményét, ha élvezetes olvasmányt nem is nyújtott, talán hasznosat igen. ${ }^{38}$

A kilenc Plutarchos-mű fordítását, amely Cassarinótól származik, négy-öt XV. századi kódex őrzi. A művek ezekben nem azonos megoszlásban találhatók. A vatikáni kódex (V), amelyet Antonio Panormita állított össze és látott el lapszéljegyzetekkel, nyolc fordítást tartalmaz. ${ }^{39}$ A palermói Biblioteca della Società Siciliana per la Storia Patria kézirata (L) hét fordítás címét őrizte meg, de néhol az ezekhez tartozó fordítás hiányzik vagy csonka, máshol pedig az ajánlás maradt el. ${ }^{40} \mathrm{~A}$ római Biblioteca Casanatense példányában $(C)$ csupán két Cassarino-fordítást találunk anélkül, hogy a fordító nevét feltüntették volna. ${ }^{41}$ Végül két további kódex szintén névtelenül őriz néhány Moralia-fordítást Cassarinótól, közöttük egy olyan művet is, amely máshol nem szerepel. ${ }^{42}$

Minthogy a lefordított művek közül a Bruta animalia szövegfeldolgozását végeztük el, vizsgálódásunk is azokra a kódexekre fog kiterjedni, amelyek ezt a fordítást tartalmazzák. ${ }^{43}$ Nem volna különösebb feladatunk a latin kódexekkel, ha nem mutatnának bizonyos pontokon jelentős eltéréseket egymástól. A szövegváltozatok kérdésével az eddigi kutatás egyáltalán nem foglalkozott. ${ }^{44}$ Kézenfekvőnek tűnt ugyanis abból a

${ }^{35}$ Resta: i. m. (6. jegyz. [1959]) 230 sk. (Quomodo adulator ab amico internoscatur), 237 (De cohibenda ira), 246 (Apophthegmata Laconica).

${ }^{36}$ Resta: i. m. (6. jegyz. [1959]) 230 (Quomodo adulator ab amico internoscatur), 234 (De capienda ex inimicis utilitate), 237 (De cohibenda ira).

37 Resta: i. m. (6. jegyz. [1959]) 230 (Quomodo adulator ab amico internoscatur).

${ }_{38}$ Resta: i. m. (6. jegyz. [1959]) 234 sk. (De capienda ex inimicis utilitate), 237 (De cohibenda ira).

39 V: Vat. lat. $3349,1^{\mathrm{r}}-12^{\mathrm{r}}$ De laude ipsius; $12^{\mathrm{v}}-44^{\mathrm{v}}$ Quomodo adulator ab amico internoscatur; $44^{\mathrm{v}}-$ $53^{\mathrm{v}}$ Bruta animalia; $53^{\mathrm{v}}-62^{\mathrm{v}}$ De capienda ex inimicis utilitate; $62^{\mathrm{v}}-78^{\mathrm{r}}$ De cohibenda ira; $78^{\mathrm{r}}-101^{\mathrm{r}}$ Septem sapientium convivium; 101 ${ }^{\mathrm{r}}-142^{\mathrm{v}}$ Regum et imperatorum apophthegmata; $147^{\mathrm{r}}-184^{\mathrm{v}}$ Apophthegmata Laconica.

40 L: Ms. Lodi XII E 13, 2 $2^{\mathrm{r}}-8^{\mathrm{r}}$ De laude ipsius; $8^{\mathrm{v}}-9^{\mathrm{v}}$ Quomodo adulator ab amico internoscatur (fordítás nélkül); $21^{\mathrm{r}}-31^{\mathrm{v}}$ Septem sapientium convivium (ajánlás nélkül); 32 $-36^{\mathrm{v}}$ Bruta animalia; $36^{\mathrm{v}}-40^{\mathrm{r}}$ De capienda ex inimicis utilitate; $40^{\mathrm{v}}-48^{\mathrm{r}}$ De cohibenda ira; $48^{\mathrm{v}}-69^{\mathrm{v}}$ Apophthegmata Laconica (a végén a fordítás megszakad).

${ }^{41}$ C: Bibl. Casanatense 665 (C II 8), 56 ${ }^{\mathrm{r}}-62^{\mathrm{v}}$ Bruta animalia; 64 $-94^{\mathrm{r}}$ Regum et imperatorum apophthegmata.

42 Vat. Ott. lat. 1398, $35^{\mathrm{r}}-47^{\mathrm{v}}$ Septem sapientium convivium; $47^{\mathrm{v}}-53^{\mathrm{r}}$ De capienda ex inimicis utilitate; $53^{\mathrm{r}}-56^{\mathrm{v}}$ De cupiditate divitiarum; Cambridge University Library Add. $6180,54^{\mathrm{v}}-56^{\mathrm{r}}$ De cupiditate divitiarum.

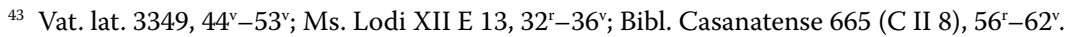

44 Teljesen mellőzte a kérdés tárgyalását Resta: i. m. (6. jegyz. [1959]) 207 skk.; G. Indelli: Traduzioni

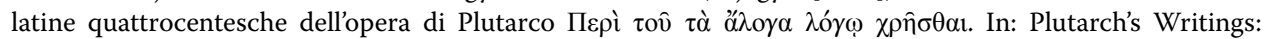
Transmission, Translation, Reception, Commentary. Eds. G. Pace - P. V. Cacciatore. Napoli 2013.227 skk.; F. Becchi: Problèmes textuels et choix d'interprétation dans les textes de psychologie animale de Plutarque. In: Plutarque. Éditions, Traductions, Paratextes. Eds. F. Frazier - O. Guerrier. Sao Paolo 2016. 155 skk. 
feltételezésből kiindulni, hogy a vatikáni kódex nyújtja a legjobb és legeredetibb szöveget, hiszen Antonio Cassarino személyes jó barátja és honfitársa, a szicíliai Panormita állította össze. A két másik szöveggel való egybevetés azonban más eredményre vezet. A szövegváltozatok egymáshoz való viszonya több réteget feltételez, amelyek közül a legrégibb egy közös archetípusra vezethető vissza. Ez a közös archetípus azonban már bizonyíthatóan egy sor olyan szövegromlást tartalmazott, amelyet a három kézirat egységesen örökölt.

A közösen örökölt szövegromlásoknak három jellemző fajtáját különíthetjük el, amelyekről elmondható, hogy egyik sem származhat magától Cassarinótól. Vagyis a közös archetípust legalább egy fázis elválasztotta a szerzői kézirattól, de a másolási hibák száma alapján valószínübb, hogy több romlási szakaszra kell gondolnunk.

Az első fajtában görög nevek romlott alakjaival találkozunk. Ezeket kisebb erőfeszítéssel vissza tudjuk állítani eredeti, tiszta formájukba néhány jellemző betűtévesztés feltételezésével. Így például 987f K

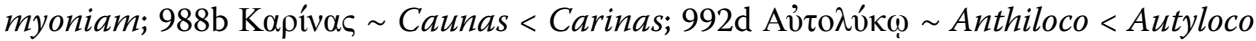
$<$ Autolyco. Az utolsó példában a Casanatense-kódex elkülönül, amelyben Ancolyco < Autolyco olvasatot találunk.

Az esetek második fajtájában egyszerű szavak romlott alakjai állnak mindhárom kéziratban. Például 987f atris < acris ${ }^{45}$; 988a malitia < militia; 988c vitae < vitat; 988d nobis < vobis; $991 \mathrm{f}$ quarundam < quorundam.

A közös hibák harmadik fajtájában egész mondatrészek hiányoznak a szövegből,

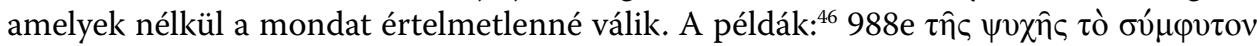

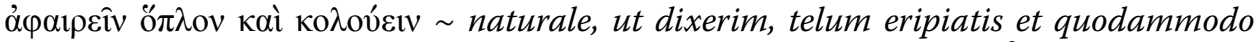

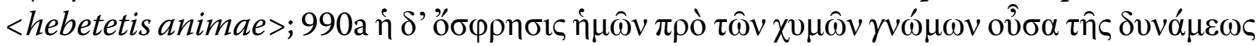

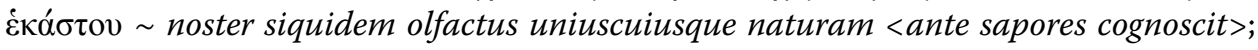

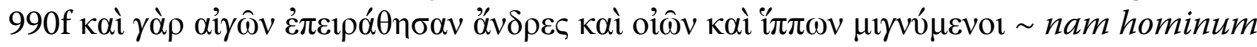
plerique cum pecudibus, capris aut equabus coire <temptaverunt $>$.

Biztosan megállapítható, hogy a felsorolt szövegromlásokat tartalmazó közös archetípust Cassarino már nem látta, mivel akkor a hibákat javította volna. De ugyanez elmondható a három kéziratról is, amelyek a hibákat örökölték. Kérdés tehát, hogy az említetteken kívül vannak-e olyan közös olvasatok, amelyekben két-két kézirat osztozik, a harmadik pedig eltér, illetve hogy ezek az eltérések mivel magyarázhatók. Egyaránt lehetséges ugyanis, hogy az egyik kódex eltérő olvasata utólagos javítást tartalmaz, bár nem Cassarinótól, valamint hogy megőrzött korábbi jobb olvasatokat, amelyek a többi kéziratban tovább romlottak. Néhány biztos támpontot nyerhetünk a görög eredetivel való összehasonlításból.

A dialógus több pontján a Lodi és a Casanatense szövegváltozatához képest a vatikáni kódex olyan beavatkozások jeleit mutatja, amelyek nincsenek összhangban a görög

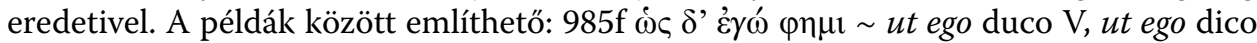

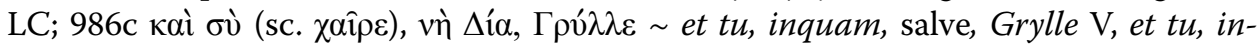

${ }^{45}$ Vat. lat. 3349, 47v a betű fölött utólag javítva.

${ }^{46}$ A <> jelek közötti mondatrészek saját kiegészítések, amelyekhez a későbbi latin fordításokból (Lampugnino Birago, Giovanni Regio) merítettük az ötletet. 
quam, Grylle LC; 991d o’ Már ennyiből is látható, hogy a kódex másolója, bizonyára maga Panormita, nem volt tekintettel a görög szövegre. Néhány további esetben sikerrel javította ugyan a két másik kódex romlott szövegét, ám nyilvánvalóan a görög ismerete nélkül. Ezek a javítások a latin fordítás jobb megértését célozták, többségükben pedig formai jellegűek voltak. A húszegynéhány szövegváltoztatás nagy része a latinos írásmódot, a szórendet, a kötőszavak és névmások használatát érinti.

A következő lépésben meg kell állapítanunk, hogy a Lodi és a Casanatense szövege között vannak-e különbségek, és ha igen, akkor a vatikáni kódex melyiket követte. Erre biztos válasz adható, mivel a vatikáni kódex néhány szöveghelye árulkodó jeleket tartalmaz, amelyek a Lodi-kódextől való szoros függésére utalnak.

A fordítás egyik tagmondatában egy feleslegesen beszúrt igealak a szövegben ma-

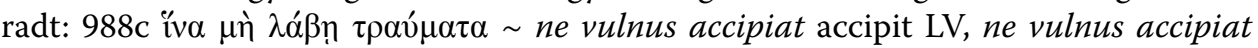
C. Máshol egy kötőszó furakodott értelmetlenül a szövegbe, amely kis változtatással

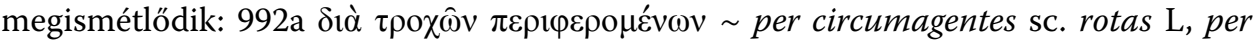
circumagentes et rotas V, per circumagentes rotas $\mathrm{C}$. Sőt egy örökölt romlott szöveg-

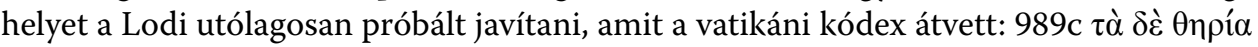

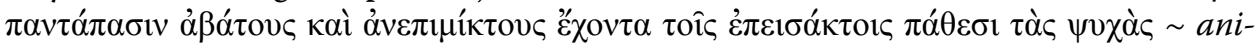
malia vero, cum sint ab externis omnino a deffectionibus ${ }^{47}$ libera $\mathrm{L}$, animalia vero, cum sint omnino a defectionibus libera $\mathrm{V}$, animalia vero, cum sint ab externis omnino a deffensoribus ${ }^{48}$ libera $C$. Már a közös archetípus szem elől veszítette a görög eredeti értelmét, ahol azokról az idegen, külső hatásokról van szó, amelyeket az állatok nem engednek be a lelkükbe. Tehát a szövegromlás az a deffensionibus < affectionibus félreírásból keletkezhetett.

A Lodi szövegkihagyásait is hủen tükrözi a vatikáni kódex. A hiányok pótlására egyszer sem folyamodik a Casanatense-kézirathoz, ami jelzi, hogy Panormita nem volt ennek a birtokában. Vagy kiegészítés nélkül hagyja a szöveget, vagy pedig értelmi

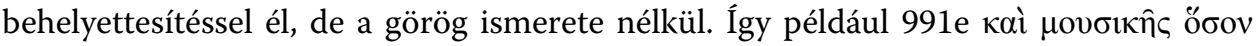

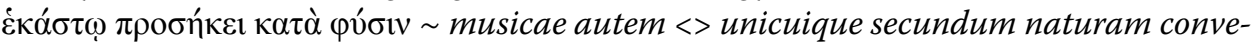
niat LV, musicae autem quantum unicuique secundum naturam conveniat $C$; $986 a$ $\alpha \lambda \lambda \grave{\alpha}$

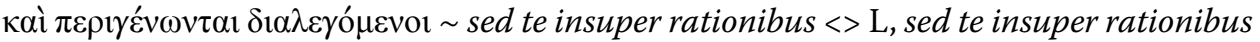
remittent $\mathrm{V}$, sed te insuper rationibus revincent $\mathrm{C}$.

Két helyen a Lodi üres kihagyással jelölte a szóhiányt, amely feltehetően olvasási nehézségből eredt. Az egyik helyre az írnok utólag beírta a „másik dolog” szavakat azért, hogy jelezze a tanácstalanságát. A vatikáni kódex mindkét helyen követte: $992 \mathrm{~d} \hat{\eta} \tau \hat{\imath} \operatorname{có} \pi \pi \omega$

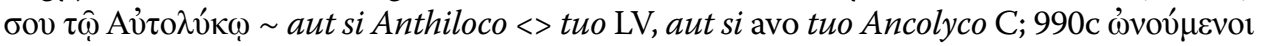

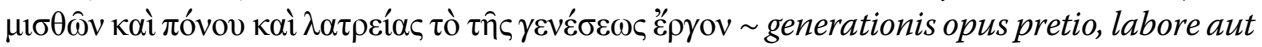
alia re coemunt LV, generationis opus pretio, labore aut servitute coemunt $\mathrm{C}$.

47 Ms. Lodi XII E 13, 34v utólag javítva deffensionibus alakból

${ }^{48}$ Bibl. Casanatense 665 (C II 8), 59v utólag javítva deffensonibus alakból. 
A legbiztosabb érv a Casanatense elsőbbsége mellett a Lodi és a vatikáni kódex közös szövegromlásaiból származik. Ezekben ugyanis a Casanatense kifogástalan olva-

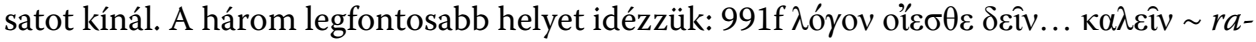
tionem appellandam consentis LV, rationem appellandam censetis $\mathrm{C}$ (consentis $<$ cen-

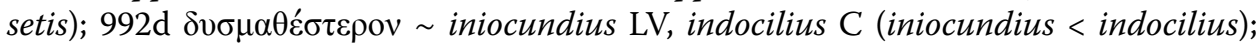

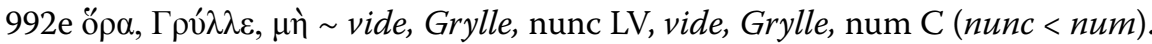

Mindebböl az következik, hogy a vatikáni kódex nem tarthat számot eredetiségre. A vatikáni kódex szövegváltozatának legvalószínűbb forrása a Lodi-kézirat, amit a számos egyezésen túl Panormita és a kódex azonos palermói származása is megerősít. Nem elképzelhetetlen, hogy a vatikáni kódex szövegének összeállításakor Cassarino barátja és honfitársa ezt a kéziratot használta. Mert bár a mai állapotában a kódex hiányos és töredékes, nem tartalmaz mást Cassarino fordításain kívül.

De milyen forrásból származott akkor az eredetibb Casanatense-szövegváltozat? Cassarino ajánlásaiból tudjuk, hogy a fordításait gyakran azzal a kéréssel küldte el a címzetteknek, hogy vagy maguk olvassák el, mielőtt terjeszteni kezdenék, vagy még egy ismerős szakértővel is nézessék át. A Bruta animalia ajánlásában Cassarino barátján kívül, akinek a fordítást elküldte, megemlít egy szakértőt is. Az ajánlás teljes szövegét itt közöljük:

Félek, legdrágább Giacomóm, ${ }^{49}$ nehogy kevéssé tünjek bőkezűnek előtted azért, mert most ezt a csekély ajándékot küldöm neked. Amit bizonyára képes vagy becsülni, még ha a lelkem nem is volna ismert számodra, vagy ha nem tudnád, menynyire át kívánok neked adni mindent. De amikor ez idő szerint elhatároztam, hogy adok neked valamit, és nem állt rendelkezésemre elegendő szabadidő (mert hát ismered jól az elfoglaltságaimat) arra, amit akartam, akkor ezt az értekezést fordítottam le neked Plutarchostól a lehető legrövidebb éjjeli munkával, nem mintha lelkem mélyéről ezt elegendőnek tartanám, hanem azért, hogy megértsd, mennyire nem kedvesebb számomra semmi sem a te tanulmányaidnál, és hogy ebben a müfajban akár még a csekélyt is mennyire nagy buzgalommal szoktam hajszolni. Ügyelj rá, nehogy bárkivel is megoszd még azelőtt, hogy a mi Balbinkkal, mindkét nyelv legnagyobb szakértőjével megtanácskoznád! Az ő segítségével ugyanis képes leszel nemcsak azt kijavítani, ha valami kevésbé megfelelően van kifejezve, hanem azt is megérteni, ha valami homályosabbnak tünik. ${ }^{50}$

A Casanatense-kézirat a Bruta animalia szempontjából kiemelt fontossággal bír, mivel Cassarino fordításai közül csak ez a mủ található meg benne, illetve még a Regum

\footnotetext{
${ }^{49}$ Az ajánlás címzettje Giacomo Curlo, Cassarino tanítványa és barátja, aki az 1440-es évek első felében maga is Genovában tartózkodott.

50 A latin szöveghez lásd Resta: i. m. (6. jegyz. [1959]) 233.
} 
et imperatorum apophthegmata. ${ }^{51}$ Viszont éppen ennek a két Plutarchos-fordításnak a jellemzője, hogy Cassarino tanítványának és barátjának, Giacomo Curlónak ajánlotta. Ahogy a Bruta animalia ajánlásában arra kéri, ossza meg közös ismerősükkel, Balbival, úgy a Regum et imperatorum apophthegmata ajánlásában Marrasio neve hangzik el hasonló összefüggésben. ${ }^{52}$ Sajnos Balbi személyazonosságát homály fedi, ${ }^{53}$ ám figyelemre méltó tény, hogy a Casanatense-kódexben a Regum et imperatorum apophthegmata ajánlásának a címzettje Curlóról felcserélődik Balbira. Ez a névcsere talán annak köszönhető, hogy Curlo továbbküldte a fordítást Balbinak, hogy szakértői szemmel átnézze. Mindenesetre valószínű, hogy a Casanatense jobb állapotú szövegének a forrását Curlónál és Balbinál kell keresnünk. Érdemes megjegyezni, hogy a kódex az utolsó felében található művek alapján erős genovai kötődést mutat. Egy Genova dicséretére elhangzó szónoki beszéddel zárul, amelyben talán Cassarino alkotását sejthetjük. ${ }^{54}$ Legalábbis a Pietro Ransano által írott életrajzban szó esik egy ilyen beszédről, amelyet Gianvito Resta annak idején hiába keresett. ${ }^{55}$

Nem érdektelen meghatároznunk, hogy vajon a Bruta animalia fordítása során Cassarino milyen görög szöveget használt. A Moralia-kódexek nagy száma és terjedelmes szöveghagyománya ellenére van remény, hogy ebben a kérdésben sikerrel járjunk. A Bruta animalia 33 kódexben őrződött meg, ${ }^{56}$ amelynek nagyjából a felét szokták felvenni a szövegkiadók a három vagy négy leszármazási ágba. ${ }^{57}$ Bár a $\Pi$-családba tartozó úgynevezett Planudés-kódexek ( $\alpha \mathrm{AEG}$ ) az összeállításuk után jelentős befolyást gyakoroltak a többi kódexcsalád tagjainak a másolására, nagyobb volt ennek a befolyásnak a mértéke a $\Theta$-család tagjainál $(\mathrm{ZuB})$, mint a $\Psi$-, illetve $\Xi$-család kódexeinek esetében (Qihk, Pq, gy). Cassarino forrásszövegének az azonosításában nagymértékben segít, hogy fordítása a $\Psi$-család egyik általunk ismert kódexének $(\mathrm{g})^{58}$ az elszigetelt olvasataival mutat félreismerhetetlen egyezéseket.

Öt helyen ez a kódex az összes többivel ellentétben kihagyott bizonyos mondatrészeket. ${ }^{59}$ Cassarino fordításában ezek a kihagyások kivétel nélkül megjelennek. A há-

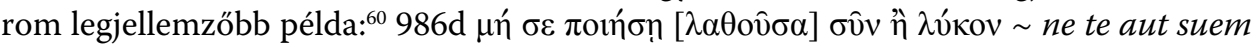

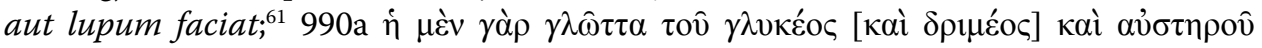

${ }^{51}$ A kódex pontos adataihoz lásd Catalogo dei manoscritti della Biblioteca Casanatense. Vol. VI. 1978. 173 skk.

${ }^{52}$ Resta: i. m. (6. jegyz. [1959]) 245. Giovanni Marrasio, Noto szülötte, bizonyára közeli ismerőse volt Cassarinónak.

${ }^{53}$ Vö. Resta: i. m. (6. jegyz. [1959]) 233, n. 1.

${ }^{54}$ Bibl. Casanatense 665 (C II 8), 127v $-135^{v}$ Laudes urbis Genuae.

${ }_{55}$ Resta: i. m. (6. jegyz. [1959]) 222; vö. Indelli: i. m. (44. jegyz.) 229, n. 22.

${ }^{56}$ A kódexek elektronikus adatbázisához lásd https://pinakes.irht.cnrs.fr.

57 Vö. C. Hubert: Plutarchi Moralia. Vol. 6. Fasc. 1. Leipzig 1954. IV skk.; G. Indelli: Plutarco, Le bestie sono esseri razionali. Napoli 1995. 35 skk. és 47 sk.; J. Bouffartigue: Plutarque, CEuvres morales. Traité 63: L'intelligence des animaux. Paris 2012. LII skk. és LXI skk.

${ }^{58}$ g: Vat. Pal. gr. 170.

${ }_{59}$ Az y-kódex (Vat. gr. 1009) pontos olvasatait nem tudtuk visszaellenőrizni, de mivel a Bruta animalia vége ebben a kéziratban csonka, ezért nem szolgálhatott Cassarino forrásául.

${ }^{60}$ A görög szövegben a kihagyásokat [] jelek közé iktattuk.

${ }^{61}$ Cassarino a dialógusnak egy másik helyén a görög $\lambda \alpha \theta \omega ́ v$ participiumot latens alakban hiánytalanul visszaadja. 


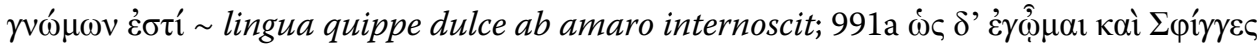

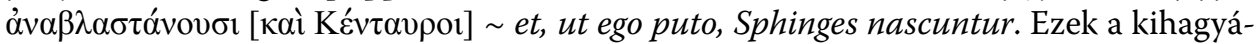
sok azt is bizonyítják, hogy Cassarino nem folyamodott más kézirathoz a fordításban az általa használt szövegváltozaton kívül, hiszen ebben az esetben könnyen javíthatta volna a szöveghiányokat.

Újabb tíz elszigetelt esetben a g-kódex kisebb-nagyobb mértékben eltérő olvasatokat közöl. Ahogy ez a fordításból megítélhető, Cassarino mindig igazodik ezekhez a szövegeltérésekhez. Egy alkalommal a látványosan eltérő olvasat a P-kódexpár egyik tagjánál ${ }^{62}$ is előkerül ugyan, ám ezt a hagyományi ágat Cassarino sehol máshol nem

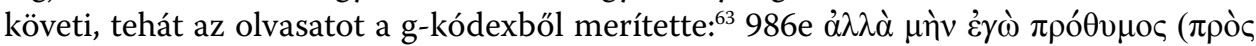
$\dot{v} \mu \hat{\alpha} \varsigma \Omega) \dot{\alpha} \kappa \rho о \hat{\sigma} \sigma \theta \alpha \mathrm{l} \sim$ sum equidem ad audiendum paratus. Két másik példa egyértelmü

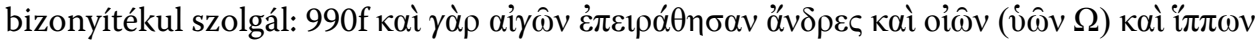
$\mu \mathrm{\gamma} v 0 ́ \mu \varepsilon v o \sim$ nam hominum plerique cum pecudibus, capris aut equabus coire; $992 \mathrm{e}$

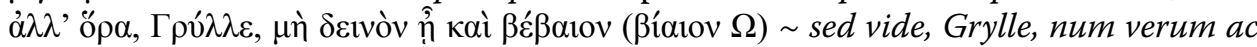
certum illud sit.

Ezek a szoros egyezések a latin fordítás és a g-kódex szövege között amellett szólnak, hogy Cassarino ezt a kódexet vagy ennek egy másolatát használta fel munkája során. Annyit biztosan lehet tudni, hogy a kódex tíz évvel Cassarino halála után, 1457-ben Giovanni Aurispa birtokába jutott, legalábbis ideiglenesen, mivel a hátsó lapon található bejegyzés szerint a firenzei Francesco Biliotti zálogba adta neki más könyvekért cserébe. ${ }^{64}$ A korábbi sorsáról nincs tudomásunk, de könnyen elképzelhető, hogy Cassarino egy időben hozzáférhetett, és talán a saját maga számára készített egy másolatot a Bruta animalia szövegéből. A g-kódexben található Moralia-művek listája alapján ugyanakkor az is kijelenthető, hogy a további Plutarchos-fordítások alapjául ez a kézirat nem szolgálhatott, kivéve esetleg a két Apophthegmata-fordítást, mivel a többi lefordított mü nem szerepel ebben a kódexben. Ha tehát valóban csak a Bruta animalia fordításához használta fel a g-kódex szövegváltozatát, akkor feltehető, hogy a kódexből kifejezetten ez a darab érdekelte.

Egykor Remigio Sabbadini így fogalmazta meg a humanista fordítás alapelvét: „Szépíteni, szépíteni, szépíteni és mindenekelőtt átváltoztatni, elvenni, hozzáadni.” 65 Szavai, melyeket azóta is gyakran idéznek, ${ }^{66}$ jó kiindulópontot szolgáltatnak azoknak a szempontoknak a meghatározásához, amelyek alapján Cassarino fordításának a vizsgálatához nekiláthatunk. A szabad fordítás általános elve mellett, amely a görög szöveg la-

62 P: Heid. Pal. gr. 153.

63 A görög szövegben a többi kódex egységes olvasatát zárójelbe téve $\Omega$ jelzettel láttuk el.

${ }^{64}$ M. Manfredini: Codici plutarchei di umanisti italiani. ASNP 17 (1987) 1034, n. 190. A bejegyzés fölött mint tulajdonos Andrea di Biagio neve is fel van tüntetve.

${ }^{65}$ R. Sabbadini: Il metodo degli umanisti. Firenze 1922. 26: Tradurre significa abbellire abbellire abbellire e soprattutto mutare togliere aggiungere.

${ }^{66}$ W. Berschin: Greek Letters and the Latin Middle Ages. From Jerome to Nicholas of Cusa. Washington 1988. 276; uö: Traduzioni dal greco in latino (secoli IV-XIV). In: I Greci: storia, cultura, arte, società 3: I Greci oltre la Grecia. Torino 2001. 1033; E. Berti: Traduzioni oratorie fedeli. Medioevo e Rinascimento 2 (1988) 251 skk.; Becchi: i. m. (23. jegyz.) 19, n. 29. 
tinra való rugalmas átalakítását jelenti, a Bruta animalia fordításában jelentős szerepet játszanak egyfelől a bővítések, hozzátoldások, másfelől a szűkítések, kihagyások.

A bővítések száma nem csekély. Ezt nyilván részben a jobb megértésre való törekvés, részben pedig a szebb stílus igénye indokolta. Nyolcvan olyan esetet számoltunk össze, amikor a fordítás valamilyen a görög eredetiben nem szereplő szóval kibővült. Ezek között vannak jelentéktelenebbek is. Jellemző például az omnis jelzővel vagy a multum / multo határozóval való bővülés, ${ }^{67}$ de hasonló szerepben további jelzők és határozók is előfordulnak. Visszatérő az etiam kötőszó, magyarázólag pedig a scilicet használata olyan mellérendelő szerkezetekben, ahol ezt a fordító szükségesnek látta. ${ }^{6}$ Hasonló megfontolásból vezette be az ut dixerim fordulatot azokon a helyeken, ahol érzékeltetni kívánta az átvitt értelmet. Az enyhébb kiegészítések sorába tartozik a fónevek mellé betoldott genera alak is a sokaságra utaló összefüggésekben, így például „sok betegség” helyett „betegségek sok fajtája” olvasható.

A felsoroltaknál lényegesebb az a mintegy harminc elöfordulás, amelyekben a bővítést nem érezzük feltétlenül szükségesnek. Ezekben Cassarino a hendiadyoin jól ismert stíluseszközéhez folyamodott annak ellenére, hogy az eredeti szövegben önmagában álló alak szerepel. ${ }^{69} \mathrm{~A}$ szemléltetés kedvéért egy-egy példát választunk a főne-

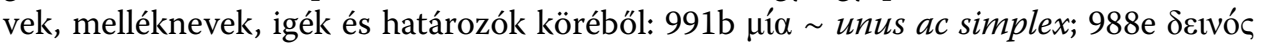

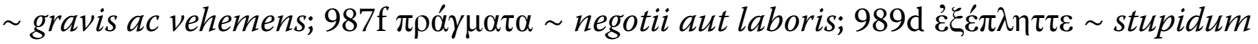
atque attonitum habebat; $988 \mathrm{f} v \varepsilon \alpha v \mathrm{i} \omega \hat{\iota} \varsigma$ mire ac nove. Olykor ennek az eszköznek a használata elburjánzik, és a kéttagú formából háromtagúba átlépve egyenesen hendiatrión formáját ölti. Egy helyen a párbeszéd állati résztvevője, Gryllos azt ecseteli Odysseusnak, hogy az állatok abból nyerik rendíthetetlen bátorságukat, amellyel felülmúlják

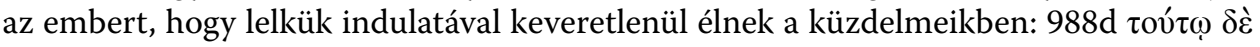

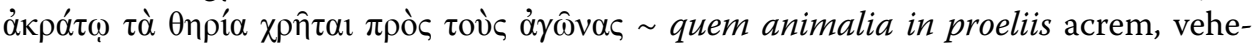
mentem indomitumque afferunt. A három jelző ugyanazt magyarázza, bár a fordításból nem egészen világos, hogy Cassarino az eredeti szót pontosan értette-e. A folytatásból ugyanis kiderül, hogy az emberek indulata keveredik a számítással, akár bor a vízzel, ezért a bátorságuk is veszít a szilajságából. Különös, hogy éppen a keveredésre utaló szavak hiányoznak Cassarino háromtagú felsorolásából. Máshol ilyen kétség nem merül fel, mivel az összefüggés egyértelmű. Arról van szó, hogy az állatokban kevés vágy lakozik,

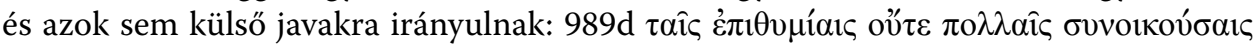

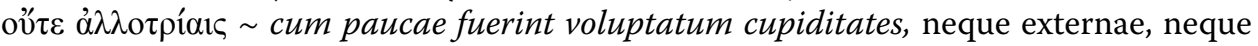
superfluae, neque accersitae. A hármas jelző tartalmát ebben az esetben Cassarino az egész fejezetből nyerte ki, ahol a vágyak hasonló megjelölései ismétlődnek.

Úgy tünik, hogy Cassarino különösebb gond nélkül folyamodott a hendiadyoin módszeréhez főnevek melléknevekkel vagy melléknevek főnevekkel való bővítése során is. Például az egyik szöveghelyen a testi gyönyörök féktelenségéről mondja Gryllos, hogy

\footnotetext{
67 Összesen nagyjából tíz alkalommal.

68 Körülbelül öt-tíz esetben.

${ }^{69}$ Giovanni Regio hasonló eljárásához később vö. Gaál: i. m. (2. jegyz.) 222.
} 
az embereket úgy elragadja, akár egy áradat. Itt a fordító kevésnek tartotta a képi megjelenítéshez a puszta főnév használatát, ezért kettős jelzővel egészítette ki: 990 \%̋ $\sigma \tau \varepsilon \rho$ vं

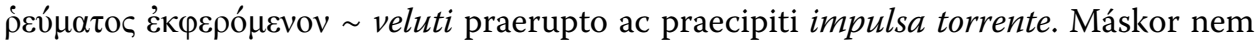
érezte elegendőnek, hogy a szöveg az állatok értelméről kijelenti, önmagát tanítja és

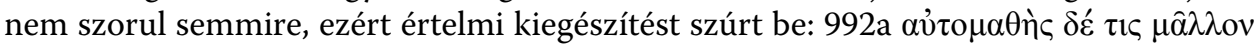

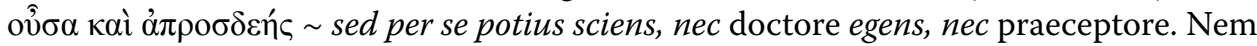
sokkal később a görög eredeti arról beszél, hogy az állatok megtehetik, hogy búcsút mondjanak a bölcsesség másoktól, tanulás útján való összegyüjtésének. Cassarino itt

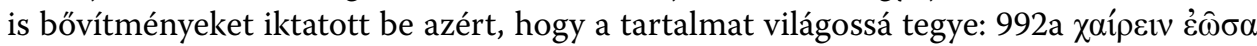

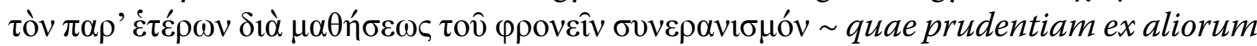
doctrina et ex rebus multis collectam atque conflatam non curat. Nyilvánvaló, hogy a

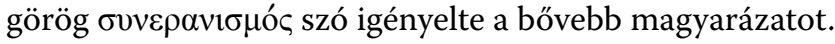

Néhány alkalommal egy-egy szó kétértelmű vagy bizonytalan jelentése okozhatta a bővítéseket. Ahol a görög megfogalmazás szerint a férfiak a vágy fullánkjától és őrjítő kényszerétől hajtva megvásárolják a testi szerelmet, ott Cassarino kétszer vette fel a fordításába az ő̋ $\tau \rho \circ \varsigma$ szót, hogy kielégítően visszaadja a metaforikus értelmet: 990c

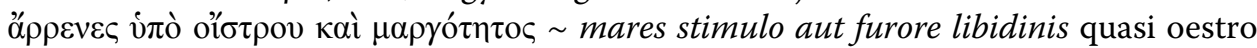
quodam allecti. A fogolymadarak rejtőzködési szokásáról azt olvassuk, hogy amikor veszélyt észlelnek, hanyatt vetik magukat, miközben egy földrögöt tartanak maguk elé a lábukkal. Cassarino talán a $\beta \hat{\omega} \lambda$ o szó használatát nem érezte elegendőnek, ezért kisebb

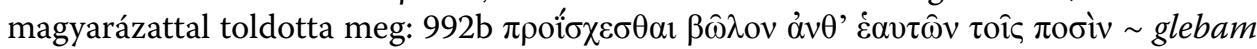
aut stramenti aliquid pedibus pro se obiciant. A legszembeszökőbb bővítést azonban egy szakkifejezésen, a platóni $\theta 0 \mu$ ó szer is igen körülményesen ír körbe. Az összefüggéssel nem ellenkezően belefordítja a

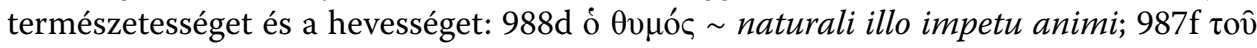

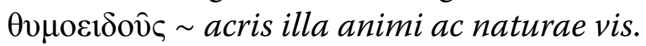

Sok szempontból a bővítések és hozzáadások tükörképét ismerhetjük fel a szűkítések és kihagyások eseteiben. Ezekből közel százat gyűjtöttünk össze. Különös, hogy a fordító az esetek egyharmadában éppen az eredeti hendiadyoin vagy hendiatrión kifejezésformát egyszerűsíti egytagúvá vagy kéttagúvá. ${ }^{70} \mathrm{Az}$ első csoportból idézünk né-

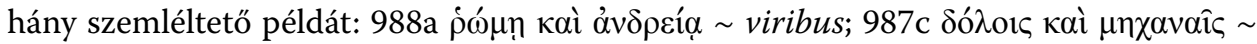

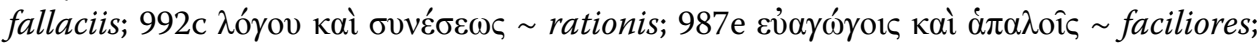

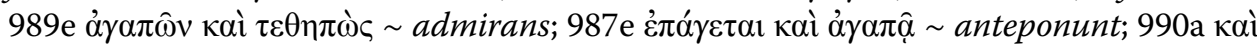

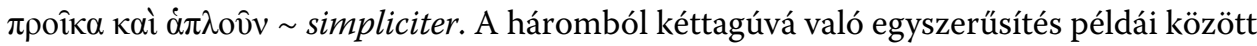
említhetjük, amikor Gryllos azt bizonygatja, hogy Ithaka földje silány, mert sok vesződség árán is csak keveset, csekélyet és értéktelent terem a megművelőjének. Cassarino a

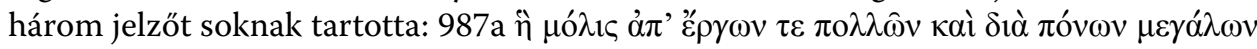

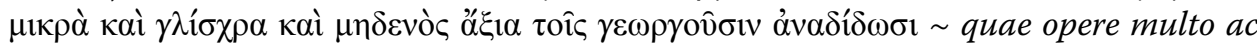
labore pauca et exilia colentibus vix reddat. Hasonlóan, amikor arról van szó, hogy az állatok utolsó lélegzetükkel is küzdenek, és egyetlen testrészükben összegyülő életerejük

${ }^{70}$ Ehhez a jelenséghez vö. Gaál: i. m. (2. jegyz.) 222. 
még egy ideig ellenáll a megölőnek, vonaglik és háborog, akkor Cassarino jobbnak látta

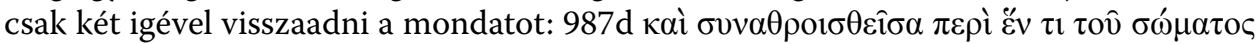

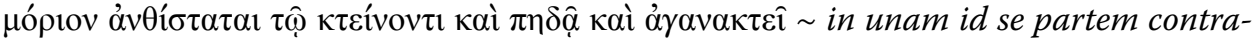
hens occidenti instat et repugnat. Vagy annak részletezése során, hogy az embernek a fákról van mit évszakról évszakra bőven leszüretelnie, összeszednie és leszakítania, úgyhogy nem kell sokat fáradoznia, Cassarino a háromból egy igét kiiktatott: 991c $\tau \rho v \gamma \hat{\omega} v \tau \imath$

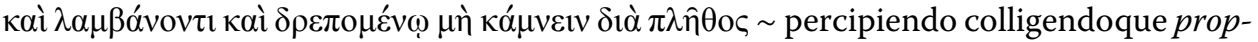
ter multitudinem non multum laborare. Érdekes, hogy egy helyen a bővítések és kihagyások rendszere sajátos ötvözetet hozott létre. Itt a két tagmondat közül az egyikben a felsorolás három tagjából egy kimaradt, a másodikban viszont a kéttagú felsorolás bővült ki egy harmadik taggal. Gryllos az állatok felsőbbrendűségét igyekszik bizonyítani azzal, hogy a költők a vadállatokhoz hasonlítják a bátor férfiakat és nem fordítva:

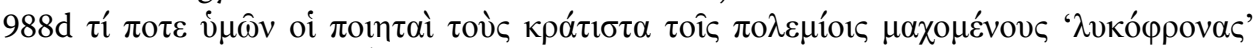

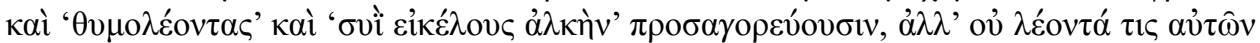

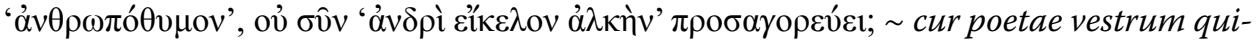
cumque sunt bello strenuissimi, lupis aut leonibus eos assimulant, nec eorum quispiam leonem aut lupum aut suem homini comparavit?

A szűkítések maradék hatvan-hetven százaléka megoszlik aszerint, hogy enyhébb vagy komolyabb kihagyásokat tartalmaz-e. Néhányszor talán csak véletlenül olyan kötőszók maradnak ki, mint a $\gamma \alpha$ $\rho$ vagy $\delta \varepsilon$, illetve egy-egy személyes, mutató vagy határozatlan névmás. Sokkal nagyobb számú viszont a főnevek, melléknevek, sőt igenevek és határozók elmaradása, vagy ritkán az igéké és kisebb tagmondatoké is. ${ }^{71}$

A fordításban nem található meg néhány általánosabb vagy különlegesebb idő- és

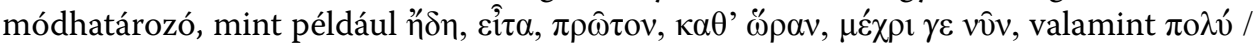
$\pi \mathrm{o} \lambda \hat{\hat{\omega}}, \mu \hat{\alpha} \lambda \lambda \mathrm{ov}, \pi \alpha \nu \tau \alpha \dot{\alpha} \alpha \alpha \sigma \mathrm{l}$. Itt a gyakoriság miatt szándékosságot sejthetünk, máskor vi-

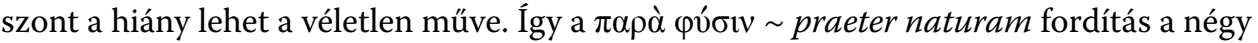
előfordulásból háromszor szabályosan megismétlődik, tehát a negyedik alkalommal va-

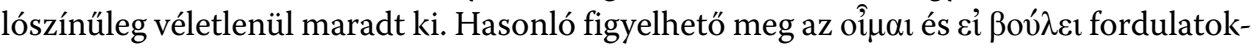
kal, amelyek váltakozva hol megjelennek a fordításban, hol pedig nem.

A kihagyások látványosabb területét képezik a főnevek és melléknevek. Feltűnő módon Cassarino többször is kerüli bizonyos főnévi bővítmények lefordítását, amelyek dativus esetben állnak, valószínűleg azért, mert úgy véli, hogy az értelem szempontjából feleslegesek. Néha valóban csak tekintethatározók és talán mellőzhetők. Máskor azonban teljes értékű bővítményt képviselnek, ezért az elhagyásuk nem tünik indokoltnak.

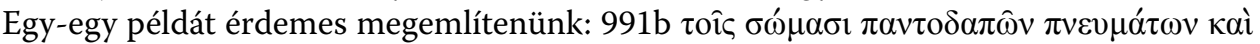
$\delta v \sigma \kappa \alpha \theta \alpha \dot{\rho} \tau \omega v$ v $\mu \alpha \hat{\alpha}, \hat{\varepsilon} \mu \pi i ́ \pi \lambda \eta \sigma \mathrm{r} \sim$ variis et inexplicabilibus morborum causis vos impli-

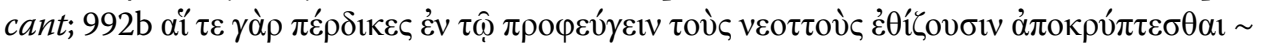

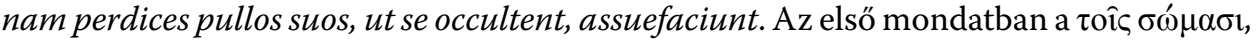

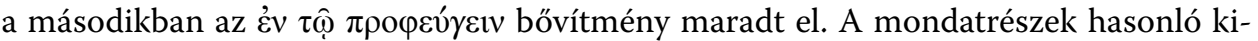
hagyását féltucat esetben figyelhetjük meg.

71 Összesen mintegy ötven alkalommal. 
Cassarino nem bajlódott bizonyos melléknevek visszaadásával. Ahogy egy korábbi példában láttuk, az embereket a vadállatokhoz hasonlító epikus jelzőket és ezek képzeletbeli párjait bonyolultnak érezte szó szerint lefordítani. Hasonlóan járt el a teuméssosi róka költői jelzőjével, illetve Apollón Ptóios melléknevével is. Feltehetően járulékos elemnek vélte, így elhagyta Pénelopé és Agamemnón neve mellől a „szép” jelzőket: 989b

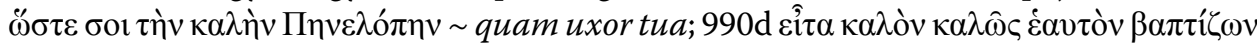

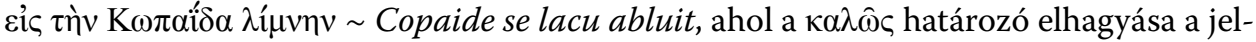
zővel együtt a szándékosságot sejteti. Gryllos az egyik szónoki érvében arra hivatkozik, hogy az embernek, aki a saját lelkének veleszületett fegyverét, a szilajságot elnyomja, nincs oka panaszkodni, hogy a természet a testét nem szerelte fel fullánkokkal, „védekező” agyarakkal és „horgas” karmokkal. Cassarino a kísérő jelzőket mindkét esetben

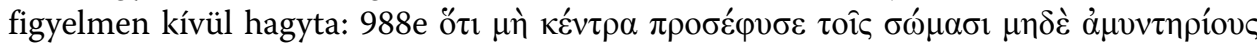

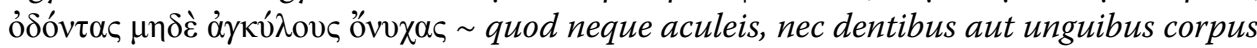
armaverit. Lehetséges ugyanakkor, hogy a melléknevek egy részét értelmi nehézségek miatt nem fordította le, vagy pedig a szeme egyszerüen átugrotta.

Ami az igéket és igeneveket illeti, Cassarino nem mindig fordítja le szívesen a participium coniunctumot. Lehetőség szerint úgy hagyja ki az összefüggésből, hogy

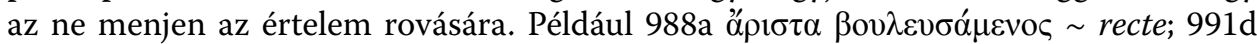

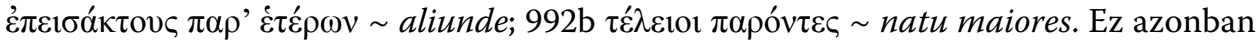
néha nem sikerül, mert értelmi hiányt okoz. Gryllos csavaros érveléssel bebizonyítja, hogy az emberek az olyan félelmet nevezik bátorságnak, amely ismeri, hogyan kell kikerülni az egyik dolgot a másik révén. Itt a teljes értelemhez az igenév lefordítása is szük-

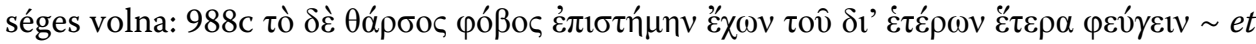
metum, qui alia propter alia vitat, audaciam nominatis. Egy esetben a gazdaságosságot egy kisebb tagmondat is megsínylette, amikor a krommyóni kocáról azt halljuk, hogy nőstény létére sok bosszúságot okozott Théseusnak. A megengedő értelmü rész fordí-

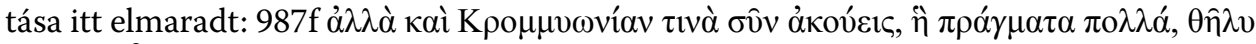

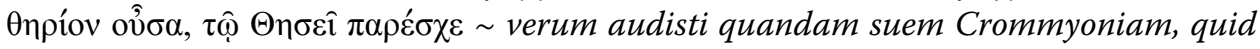
negotii aut laboris Theseo exhibuerit. Egyébként az igekihagyás egyik ritka példája is egy igeneves szerkezethez kötődik. Gryllos, a disznó elmondja, emlékszik, amikor még emberi életében megpillantotta Odysseust Krétán díszes öltözetben. Az emlékezés igei

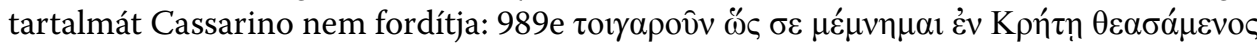

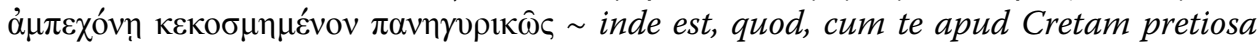
chlamyde ornatum vidissem.

A bővítések és szűkítések száma és jellege sokat elárul Cassarino fordítási gyakorlatáról. Az „értelem szerinti” (ad sententiam) fordítási módszer másik fó ismérvét azonban az átváltoztatásra, átalakításra való hajlam nyújtja. Ennek fokozatai eltérőek lehetnek, ami a transduco elvén alapuló, új humanista fordítás későbbi bírálatát is kiváltotta, és elvezetett a traduttore-traditore szópárral kifejezett azonossághoz, mely szerint a fordító nem csupán átültet vagy átváltoztat, hanem egyenesen megmásít. ${ }^{72}$ Ám nincs

72 Vö. Berschin: i. m. (66. jegyz. [1988]) 276. 
okunk Cassarinóval szemben ennyire szigorúan ítélni. Gyakori ugyan, hogy a szabad fordítás jegyében a szavaknak nem szó szerinti fordítását adja ${ }^{73}$ összességében azonban jól megragadja az eredeti összefüggéseket. Megpróbáljuk a következőkben nagy vonalakban összefoglalni, hogy milyen fordítási technikákat alkalmaz, beleértve a stílus elegánsabbá tételére irányuló kísérleteit.

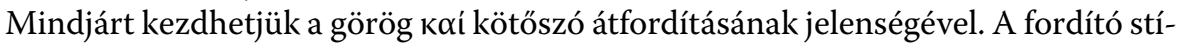
lusérzékét zavarhatta, hogy az eredetiben sürün ismétlődő kötőszót mindig az et vagy az atque / ac szavakkal adja vissza, ezért harmincon felüli esetben az aut kötőszóval fordítja. Persze főleg kéttagú mellérendelésekben folyamodik ehhez a megoldáshoz, jellem-

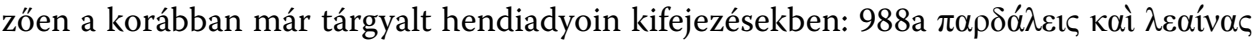

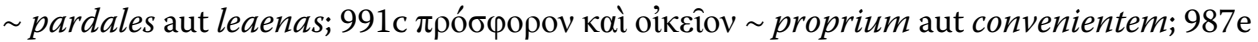

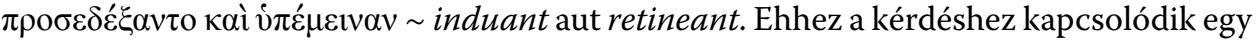
rejtélyesnek tűnő eljárásmód, amelyre nem könnyű magyarázatot találni. Számításaink szerint negyven esetben a felsorolások tagjai egyszerűen felcserélődnek az eredetiben található sorrendhez képest. Néha állhat értelmes megfontolás az eljárás mögött, mint például a szántás-vetés esetében, ahol a magyar kifejezés is meghatározott sorrendet

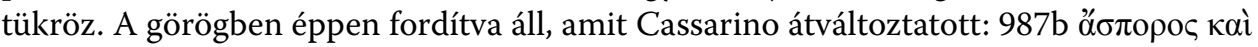

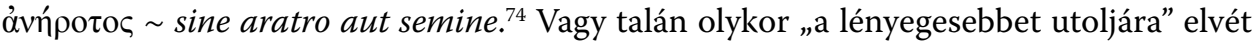
ismerhette fel a görög felsorolásban, ezért fordított a sorrenden, mint a repülö, úszó

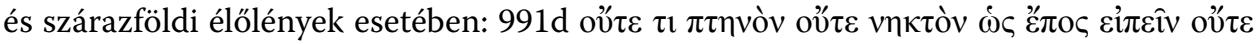

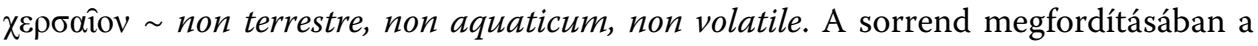
szavak ritmusa vagy a jóhangzás is szerepet játszhatott. Egységes rendszert azonban nehéz felfedezni a cserék mögött, amelyek főnevekre, melléknevekre és igékre egyaránt

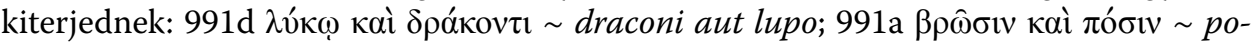

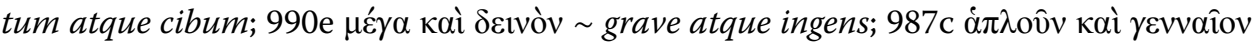

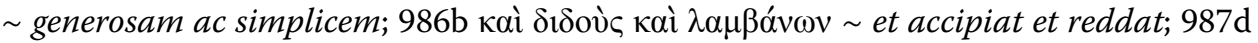

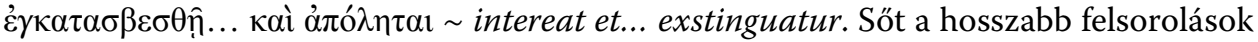
bonyolult képletekbe is rendeződhetnek. Például az első és a második tag felcserélődik, az utolsó viszont nem, vagy az első tag helyére lép a negyedik, a maradék három pedig változatlan sorrendben követi egymást.

Összhangban ezekkel a megfigyelésekkel Cassarino fordításában egyértelmű hajlam tapasztalható a nyelvtani szempontok felcserélésére, megfordítására. Az igék személyének és számának a megváltoztatása gyakori jelenség. Olyan esetekben, amikor a fordító passzív mondatot alakít át aktívvá vagy fordítva, ez érthető is. Azonban az átalakítás a vártnál többször megtörténik akár első vagy második személyből harmadikba, akár harmadik személyből másodikba. Gryllos, amikor visszaemlékszik arra, hogy Krétán megpillantotta díszes öltözetben Odysseust, elmondja, hogy nem a bölcsességét vagy az erényét irigyelte, hanem a bíborruhája kápráztatta el. Az alanyi és tárgyi szem-

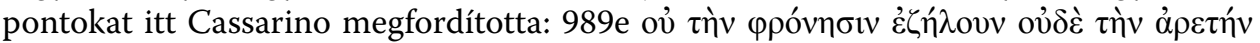

73 A névszók és igék esetében egyaránt legalább harminc-harminc alkalommal.

74 Ugyanígy járt el Giovanni Regio is később a saját fordításában. 
$\sim$ nequaquam me prudentiae aut virtutis tuae ardor capiebat. Ugyanebben az összefüggésben meséli el Gryllos, hogy mivel folyton a javak utáni vágyakon csüngött, elmulasztotta, hogy az egyszerúbb élvezetekkel éljen. Cassarino ebben az esetben is hasonló

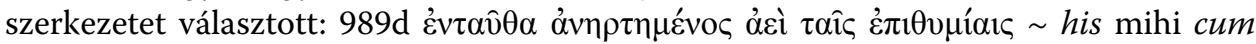
animus semper cupiditatibus aestuaret. Máshol a szöveg úgy fogalmaz, „halljuk”, hogy minden egyiptomi orvos is egyben, amit Cassarino egyszerűen a „mondják” igével cse-

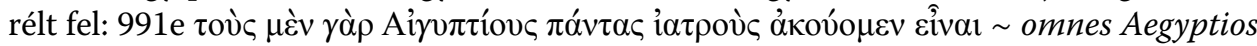
medicos esse aiunt.

A jelenség második személyü alakokkal is előfordul, amelyeket Cassarino áthelyez harmadik személybe. Gryllos azokkal a szavakkal fordul Odysseushoz, hogy a vágyak között számos különbséget figyelhet meg. A fordításból itt Cassarino kiiktatja a sze-

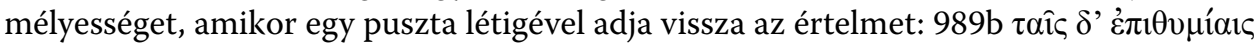

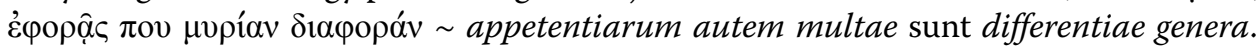
Egy másik helyen Gryllos azt mondja a hősnek, hogy ha nem hiszi el, hogy az állatok megtanulják a mesterségeket, akkor tudja meg, hogy még tanítják is. Cassarino ebben az

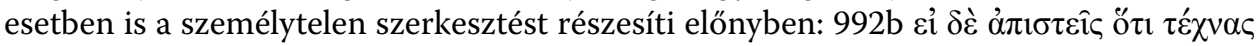
$\mu \alpha v \theta \alpha ́ v o \mu \varepsilon v \sim$ si autem praeter fidem videtur nos artes addiscere. De mielőtt azt hinnénk, hogy fordított eset nem következhet be, Cassarino máshol a „bizonyul” és „kell” jelentésű igéket második személyü fordításokkal látja el: $988 \mathrm{c}$ oü $\tau \omega \varsigma \delta^{\prime}{ }^{\alpha} v \alpha \varphi \alpha i ́ v \varepsilon<\tau \alpha>1$

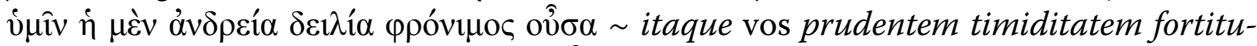

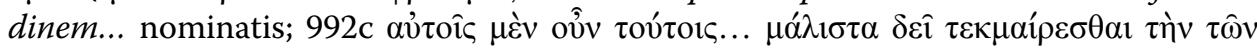

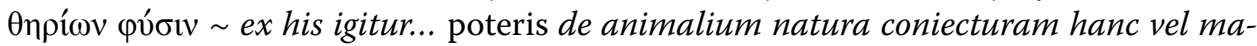
ximam facere.

Az átalakítások során a fónevek alanyi, tárgyi és más esetviszonyai természetesen átrendeződnek. Hogy a legegyszerübb példával éljünk, az egyes állatok táplálékának felsorolásában a nyelvtani esetek a görög eredetiben és a latin fordításban éppen

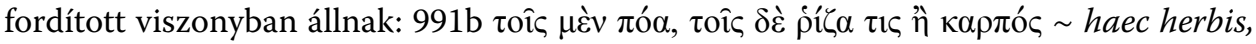
illa radicibus aut fructibus vivunt. Az ehhez hasonló példák száma jelentős Cassarino fordításában. A müködési elv a közép- és felsőfokú összehasonlításokban nyilvánul meg a legvilágosabban. A dialógus legvégén Gryllos az állati értelem bizonyítékaként azt javasolja Odysseusnak, hogy hasonlítsa össze az okos állatokkal a butákat, ahogy saját magával összehasonlítaná Polyphémost. A fordításban az összehasonlítás szempontjai

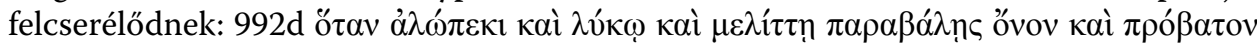
$\sim$ cum scilicet asino aut pecudi vulpem aut lupum vel apem comparaveris. Ugyanez történik meg, amikor Gryllos az aranyról beszél, mint olyan kincsről, amely semmi más-

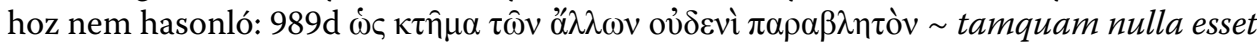
possessio huic comparanda. Cassarino fordításában viszont nincs olyan kincs, amely az aranyhoz hasonló.

Ezek a példák jól szemléltetik a humanista fordítás cicerói alapelveken nyugvó módszerét. A latin fordítás nem attól lesz ékesszóló vagy hatásos, hogy mindig pontosan ugyanott és ugyanazokat a stíluselemeket használja, mint az eredeti mintája, hanem a fordítónak úgy kell a megfelelő időben és módon kiválogatnia a műfajhoz illő stílus- 
eszközöket, hogy a saját nyelvének a követelményeihez igazodik. Cassarino ezt az elvet alkalmazta már a bővítéseknél és szúkítéseknél is. Sok esetben nem ott és nem úgy élt a két- vagy többtagú mellérendelések eszközével, ahogy a görög eredeti. ${ }^{75} \mathrm{Az}$ átalakításokkal hasonlóan járt el, amikor a felsorolások tagjait vagy a nyelvtani esetviszonyokat a fordítói szabadság nevében felcserélte. ${ }^{76}$ Még egyetlen eljárásmódot említünk meg, amely a mondatalkotás szintjén is hozzájárul a jelenség szemléltetéséhez.

Cassarino hozzávetőleg tizenöt esetben szabad átjárást enged a mondatfajták között. Elsősorban az állító és tagadó, illetve felszólító és tiltó mondatokat cseréli fel egy-

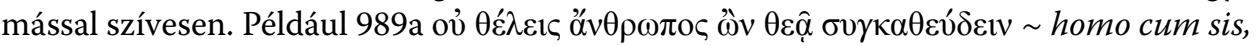

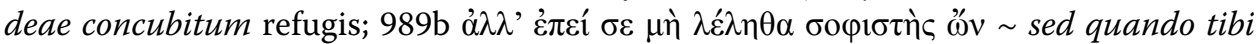
rhetor sum visus. Míg Gryllos kijelenti Odysseusnak, hogy láthatja, az állatok küzdelmei, amelyeket egymással és az emberekkel vívnak, mennyire híján vannak a csalásnak és mesterkedésnek, addig Cassarino a fordításában ugyanezt kérdő mondattá alakítja

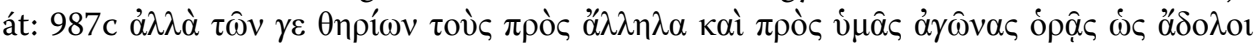

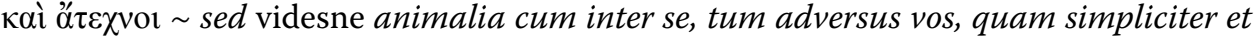
sine dolo proelientur? Amikor Kirké felszólítja a hőst a dialógus elején, hogy nyugodjon meg, ő majd gondoskodik róla, hogy az állatok képesek legyenek a beszédre, Cassarino

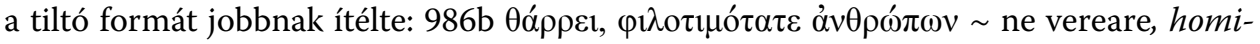
num prudentissime! Tagadás és kérdés együttesen váltja fel a felszólítást egy esetben, amikor Odysseus Kirkéhez fordul, hogy adja oda neki a görög férfiakat, akiket kért: 986a

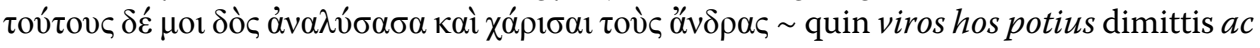
dono mihi eos tradis? Példáink sorozatát azzal az esettel zárjuk, amikor, legalábbis részben, egy kérdés alakul át felszólítássá. Gryllos ezekkel a szavakkal fordul Odysseushoz a

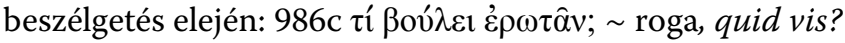

Antonio Cassarino fordítási módszeréről összefoglalóan megállapíthatjuk, hogy miközben a szöveghűség alapvető szabályait nem hágja át, kellően nagy számú esettel bizonyítja, ${ }^{77}$ hogy a fordító nem tartotta a görög eredeti betűjét megváltoztathatatlannak. A szövegeltérések alapján a fordítását akár még elnagyoltnak is nevezhetnénk. ${ }^{78}$ Bizonyára úgy érdemes felfognunk a nagyfokú eltérést, hogy Cassarino nem egyszerüen lefordítani kívánta az eredeti szöveget, hanem a szó humanista értelmében átültetni latin nyelvre ${ }^{79}$ amely bizonyos átszellemültséget igényelt. A fordításnak ebben a módjában az eredeti szöveg betűjének a tekintélye elvész, sokkal fontosabb az újraalkotás, újraformálás müvelete, amihez az ókori szerző csak nyersanyagot és mintát szolgáltat. Így egyfelől magyarázatot nyer a számos fordítói nagyvonalúság és engedékenység, másfelől érthe-

75 A legalább hetven eset fele-fele arányban oszlik meg a bővítések és szűkítések között.

${ }^{76}$ Körülbelül újabb hatvan esetben.

77 Mindent összevéve a háromszázat meghaladó szövegváltoztatással, amelyben nyolcvan bővítés, száz szűkítés és újabb száznyolcvan átalakítás található.

78 Vö. Gaál: i. m. (2. jegyz.) 228.

79 A transfero és a transduco fogalmi különbségéhez lásd Sabbadini: i. m. (26. jegyz.) 201 skk.; G. Folena: „Volgarizzare” e „tradurre”: idea e terminologia della traduzione dal Medio Evo italiano e romanzo all'Umanesimo europeo. In: La traduzione. Saggi e studi. Trieste 1973. 92 skk.; Gualdo Rosa: i. m. (26. jegyz.) 178 sk.; Berschin: i. m. (66. jegyz. [1988]) 275 skk.; uö: i. m. (66. jegyz. [2001]) 1033; Berti: i. m. (26. jegyz.) 5 sk. 
tővé válik Cassarino személyes hitvallása is arról, hogy a fordítói tevékenység miért nem kevésbé méltó az elismerésre. A fordító bizonyos szempontból maga is alkotóvá lép elő.

A másik számunkra fontos személy, aki mintegy negyed évszázaddal elődje után öt Moralia-darab, közöttük a Bruta animalia fordítását is elkészítette, a milánói Lampugnino Birago. Cassarino kortársaként a XIV. század végén születhetett, és életének első felét Milánóban töltötte, ahol jelentős közügyi feladatokat látott el Filippo Maria Visconti herceg szolgálatában. ${ }^{80}$ Közeli ismeretségben állt Pier Candido Decembrióval, illetve Francesco Filelfóval, aki mint udvari költő hosszú évtizedeken keresztül Milánóban tartózkodott. A herceg 1447-ben bekövetkezett halála Birago életében változást hozott. Az ezt követő időszakban a rövid életűnek bizonyuló Ambróziánus Köztársaság mellett kötelezte el magát, és küzdött Francesco Sforza hatalomra jutása ellen. 1450-ben azonban a város egyéves ostroma után hiába próbálta lecsillapítani a fellázadt néptömeget, amely elkergette, és Sforza bevonulásával végleg távoznia kellett Milánóból. Ezek az események új fejezetet nyitottak Birago életében. Nem sokkal később már a római udvarban találjuk V. Miklós pápa mellett, akinek a görög szerzők latinra fordítását célzó nagy vállalkozásában valószínúleg részt vesz. Konstantinápoly 1453-as eleste után Strategicon adversum Turcos címmel egy önálló müben megírja kidolgozott tervét a pápának arról, hogyan kellene a törökök ellen keresztes hadjáratot indítani. ${ }^{81}$ Bár vélhetően nagy elismerésben részesült ezért a müért, sem ez idő alatt, sem később nem hagyott fel a görögből való fordítással. A legjelentősebb kísérleteként tarthatjuk számon a halikarnassosi Dionysios Antiquitates Romanae című művének lefordítását, amelyet több szakaszban készített el V. Miklós és II. Pál pápaságának ideje alatt. Említést érdemelnek továbbá Xenophón-fordításai, az Oeconomicus című dialógus és az Anabasis, illetve Plutarchos Artaxerxés-életrajza. A két utóbbi perzsa témájú müre, amelyeknek csak a közös ajánlása maradt fenn, valószínủleg a nagy keleti ellenségre, a törökre való utalás lehetősége miatt esett a választása.

Birago életének már az utolsó szakaszára, II. Pál pápaságának az idejére esnek a plutarchosi Moralia-művekből készült fordításai. Ezeket egy rövid, közös ajánlással látta el, amelyet a pápának címzett:

Hogy a te tiszteletedre, Legboldogabb Atya, mindig készüljön valami, a minap kiválogattam Plutarchos erkölcsi műveiből azt a keveset, amelyet, ahogy a képességeimből tellett, lefordítottam latinra, és a legkegyelmesebb Szentségednek felajánlom, saját magamat a legteljesebben rábízva. A műveknek a címei pedig ezek: önmagunk dicséretéről avagy a hallgatók irigységéről; hogyan különböztetheti meg az ember a baráttól a hízelgőt; a haragtól való óvakodásról; vajon használnak-e értelmet az oktalan állatok; apophthegmata avagy spártai mondások. ${ }^{82}$

${ }^{80}$ Birago életrajzi adataihoz és munkásságához lásd M. Miglio: Birago, Lampugnino. DBI 10 (1968) 595 skk.; I. M. Damian: Lo Strategicon adversum Turcos di Lampugnino Birago. Roma 2017. VII skk.

${ }^{81}$ A mű közelmúltban megjelent szövegkiadásához lásd Damian: i. m. (80. jegyz.).

${ }^{82}$ Vat. lat. 1887, $1^{\mathrm{r}}$. A müvek a ma elfogadott címük alapján: De laude ipsius, Quomodo adulator ab amico internoscatur, De cohibenda ira, Bruta animalia ratione uti, Apophthegmata Laconica. 
Feltűnő, hogy a plutarchosi művek szinte teljesen megegyeznek azokkal, amelyeket Cassarino fordított le, sőt még a sorrendjük is azonos azzal, amit a Panormita-féle kódexben találunk, ${ }^{83}$ kivéve hogy a Bruta animalia és a De cohibenda ira helyet cserélt egymással, illetve hogy Birago a fordításból kihagyott három művet. Ezek a De capienda ex inimicis utilitate, a Septem sapientium convivium és a Regum et imperatorum apophthegmata. Tudjuk azonban, hogy éppen ez a három plutarchosi mü az, amelyeknek a Cassarino óta eltelt években készült fordítása: Giovanni Aurispa és Niccolò Perotti jóvoltából a Septem sapientium convivium fordítása született meg, ${ }^{84}$ Janus Pannoniusnak pedig a Regum et imperatorum apophthegmata és a De capienda ex inimicis utilitate fordítása köszönhető. ${ }^{85}$ Igaz, Francesco Filelfo is előállt időközben az Apophthegmata Laconica fordításával, ${ }^{86}$ ami viszont láthatóan nem akadályozta meg Biragót abban, hogy újrafordítsa. Figyelembe kell azonban venni, hogy Biragót nagyon szívélyes viszony füzte Filelfóhoz, ezért nem kellett nehezteléstől tartania.

Amikor Cassarino 1447-ben váratlanul meghalt, Panormita, éppen úgy, ahogy Giacomo Curlo, Aragóniai Alfonz nápolyi udvarában élt, ${ }^{87}$ ahová maga Cassarino is készült áttelepülni Genovából. Ugyanebben az évben következett be Birago életében is a változás a milánói herceg halálával. Hogy Sforza ellen szövetségeseket gyüjtsön, egy ideig maga is a nápolyi udvarba járt a következő egy-két évben. ${ }^{88} \mathrm{Nem}$ kizárt, hogy Birago ebben az időszakban hozzáférhetett Cassarino Plutarchos-fordításaihoz, amelyet Panormita gondozott, vagy pedig Curlótól szerzett egy másolatot. Mindenesetre érdekes, hogy Filelfo egy 1449-es levelében megdicséri Biragót, amiért immár érett életkorban görög irodalommal kezdett foglalkozni, amit okos elhatározásnak nevez, mivel a véleménye szerint görög műveltség nélkül senki sem válhat a latinság kiváló ismerőjévé. Egyúttal biztosítja afelől, hogy semmilyen kódexet vagy ismeretet nem fog tőle megvonni a jövőben. ${ }^{89}$

Láttuk, hogy Filelfo 1440-ben, miután a keze ügyébe jutott Cassarino egyik fordítása, görög nyelvü levélben nyilvánította ki tetszését, és ajánlotta fel barátságát Cassarinónak. ${ }^{90}$ Ugyanennek az évnek a következő hónapjában Biragónak is küldött egy görög levelet, amelyben azt írja, hogy szívesen tesz eleget barátja kérésének, és küldi el neki

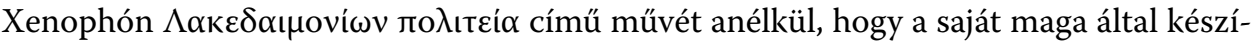

${ }^{83}$ Az észrevételhez a kérdés további tárgyalása nélkül vö. Resta: i. m. (6. jegyz. [1959]) 229, n. 1, 248, n. 2; Indelli: i. m. (44. jegyz.) 235, n. 67; Damian: i. m. (80. jegyz.) XLI.

${ }^{84}$ Resta: i. m. (6. jegyz. [1959]) 244; Bevegni: i. m. (23. jegyz.) 79 sk.; Becchi: i. m. (23. jegyz.) 25 és 27 sk.

${ }^{85}$ Resta: i. m. (6. jegyz. [1959]) 235; Bevegni: i. m. (23. jegyz.) 79 sk.; Becchi: i. m. (23. jegyz.) 29.

${ }^{86}$ Resta: i. m. (6. jegyz. [1959]) 248; Bevegni: i. m. (23. jegyz.) 79 sk.; Becchi: i. m. (23. jegyz.) 26 sk.

87 Az egyik mint udvari költő, a másik mint kancellár.

${ }^{88}$ Vö. Damian: i. m. (80. jegyz.) X skk.

${ }^{89}$ Francisci Philelfi viri grece et latine eruditissimi Epistolarum familiarum libri XXXVII. Venetiis ex aedibus Joannis et Gregorii Fratres, MDII, $44^{v}$ (= 06.73 De Keyser): Laudo bonitatem ingenii tui, qui aetate iamdudum ingravescens des operam graecae litteraturae... Prudenter igitur tibi consuluisti.

${ }_{90}$ Legrand: i. m. (13. jegyz.) 34 sk. (= 04.09 De Keyser). 
tett latin fordítást mellékelni tudná, mert az nincs nála. Kéri viszont Biragót, írja meg mielőbb a véleményét erről a műről, hogy tetszett-e neki. ${ }^{91}$ A Filelfóval váltott levélből kiderül, hogy Birago, noha a görög irodalommal való foglalkozást csak később kezdte el, már egy évtizeddel korábban is birtokában volt a nyelvnek annyira, hogy képes legyen elolvasni Xenophón művét. A görög levél, amelyet Filelfo küldött, feltételezi Biragóról, hogy a választ megérti ezen a nyelven, ha esetleg a kérését ő maga latinul küldte is el. Nyugodtan megállapíthatjuk tehát, hogy Birago erre az időre már tudott görögül.

Ha Cassarino Plutarchos-fordításaihoz Birago már hozzájutott is a fordítói pályafutásának kezdetén, arra csak később szánta el magát, hogy újrafordítsa a műveket. Árulkodó lehet az a kérdés, amellyel az 1460-as évek elején Pier Candido Decembrióhoz fordult egy levélben. Azt kérdezi, milyen ember volt Cassarino, de persze az önérzetében a platóni Respublica újrafordítása miatt mélyen megsebzett Decembrio kígyótbékát kiált a szicíliai fordítóra. ${ }^{92}$ Viszont Birago kérdése, amennyire meg lehet ítélni, finom érzékenységre vall. Talán vágyott közelebbről megismerni azt az embert, akinek olyan sok időt töltött a fordításaival. Ahhoz ugyanis nem férhet kétség az öt lefordított Moralia-mü sorrendje és azonossága alapján, hogy Birago válogatása Cassarino fordításából indult ki.

De vajon Birago mikor és hol tanult meg görögül? A legkézenfekvőbb válasz erre a kérdésre az volna, hogy Filelfónál Milánóban vagy a paviai egyetemen, ahol utóbbi a retorika tanszéket vezette. Ám Filelfo csak 1439-ben költözött Milánóba, hogy azután negyven évet töltsön ott, azt pedig láttuk, hogy már az 1440-es levele tanúskodik arról, hogy Birago tud görögül. Elvileg lehetséges volna, hogy Birago még akkor hallgatta Filelfót, amikor ő az 1430-as évek elején Firenzében a görög tanszéket vezette. Ennek azonban nem maradt fenn semmilyen nyoma. Úgy tünik, hogy Filelfo Biragóról inkább mint a bizalmába fogadott barátjáról, mintsem a tanítványáról beszél. Megosztja vele Plutarchos- és Xenophón-kéziratait, ${ }^{93}$ ajánlólevelet küld II. Pius pápának Birago érdekében, ${ }^{94}$ amikor pedig 1472-ben Birago meghal - ahogy Filelfo fogalmaz - már élemedett korban, betegen és a fél szemére vakon, szomorúan közli a hírt a gázai Theodórosszal. ${ }^{95}$

Felmerült az a lehetőség is, hogy Birago a gázai Theodóros, illetve Guarino Veronese tanítványa volt, amire az a tény mutatna, hogy 1449-ben biztosan megfordult Ferrarában. ${ }^{96}$ Amikor Filelfo közli Theodórosszal a gyászhírt, kétségtelenül olyan sza-

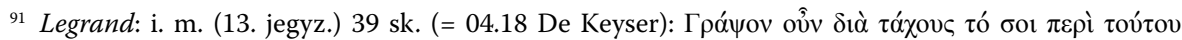

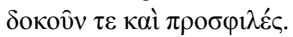

92 Resta: i. m. (6. jegyz. [1959]) 269.

93 Amelyeknek később próbál a nyomára bukkani, vö. Damian: i. m. (80. jegyz.) XVII, n. 31 és XXV sk.

${ }^{94}$ Francisci Philelfi viri grece et latine eruditissimi Epistolarum familiarum libri XXXVII, $108^{\mathrm{r}}(=$ 15.23 De Keyser). Hasonló közbenjáráshoz Borso d'Este hercegnél vö. 124 $4^{\mathrm{r}-\mathrm{v}}$ (=18.10-11 De Keyser).

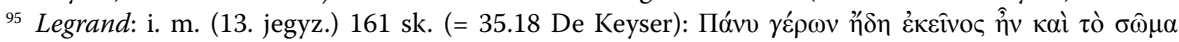

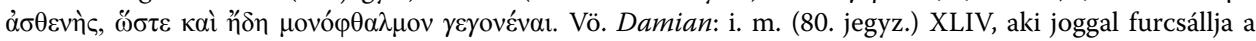
Biragóval egykorú Filelfo szavait.

96 F. Tissoni: Le Olimpiche di Pindaro nella scuola di Gaza a Ferrara. Messina 2009. 19 sk. A ferrarai tartózkodásról egy levél tanúskodik, melyhez vö. Damian: i. m. (80. jegyz.) X sk. 
vakat használ, amelyek bensőséges viszonyra utalnak. ${ }^{97}$ Itt megint az évszámok okoznak bonyodalmat, hiszen a gázai Theodóros csak 1447-től volt megtalálható a ferrarai egyetemen, Birago viszont már 1440-ben jól olvasott görögül. Egyébként sincs túl sok okunk feltételezni, hogy Birago hosszabb időre elhagyta volna Milánót életének első ötven évében. Életútja sok tekintetben rokon azzal, amit kortársa és barátja, Pier Candido Decembrio befutott. Mindketten Milánóban éltek Filippo Maria Visconti szolgálatában, a Köztársaság mellé álltak, majd amikor távozniuk kellett, V. Miklós pápánál kerestek menedéket. ${ }^{98}$ Decembrio a görög nyelvet saját magától tanulta meg az 1430-as évek elején úgy, hogy Chrysolóras 'E $\rho \tau \eta ́ n \alpha \tau \alpha$ című nyelvtanát és görögül-latinul párhuzamosan olvasható szövegeket használt, többek között Plutarchos-életrajzokat. Emiatt bizonyos lenézéssel kezelték a magasabb humanista körökben, ahol ezt a tanulási módszert kifogásolhatónak tartották. Kezdetben a fordításai is mind olyan művekből készültek, amelyeknek már volt latin nyelvű változatuk. És bár Decembrio is osztotta azt az elvet, hogy a fordításnak az értelmet, nem pedig a szavakat kell követnie, a gyakorlatban mégis sok szempontból inkább a középkori „szóról szóra” (ad verbum) módszert alkalmazta, határozottan kijelentve, hogy az eredeti görög szöveghez a végletekig hűnek kell maradni. ${ }^{99}$ Úgy véljük, hogy Birago a görög tanulásával hasonló utat járhatott be, nagyjából ugyanabban az időben, mint Decembrio, az 1430-as években. A legismertebb fordításáról, amelyet a halikarnassosi Dionysios történeti művéből készített, a szövegkiadók megállapították, hogy nyers és durva, a latin nyelv eleganciáját nélkülözi, viszont értékes abból a szempontból, hogy a szóról szóra való fordítás miatt, amelyet követ, több helyen képes a helyes olvasat nyomára vezetni. ${ }^{100}$ A plutarchosi Moralia-müvek, elsősorban a Bruta animalia fordításában ez az aggályos pontosság és iskolás pedantéria valóban megfigyelhető, és Birago fő ismertetőjegyét képezi.

Az öt Moralia-darab fordítása két XV. századi kódexben őrződött meg. Az egyik a pápának benyújtott vatikáni kódex $(\mathrm{V}){ }^{101}$ a másik pedig a római Biblioteca Angelica egy kevéssé ismert kézirata (A). ${ }^{102}$ Néhány közös másolási hiba a Bruta animalia szövegében egy már eleve romlott archetípust jelez. A példák közül kettő tulajdonnevek félreírásából származik, úgymint a mendési kos, illetve Apollón Ptóios mellékneve:

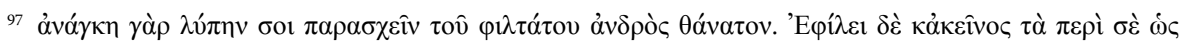

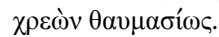

98 Pier Candido Decembrio életének eseményeihez lásd Hankins: i. m. (17. jegyz.) 117 skk.

99 Hankins: i. m. (17. jegyz.) 119 skk.

100 J. Hudson: Dionysii Halicarnassensis Antiquitatum Romanarum libri quotquot supersunt. Oxford 1704. [VIII]: quae rudior licet fuerit et inculta, Latinaeque dictionis elegantia destituta, aliquo tamen in pretio esse debet, quod eam prae se ferat interpres fidem et simplicitatem, ut Graeca, ubi minus intelligeret, de verbo ad verbum expresserit, atque ita plurimis in locis ad verae lectionis investigationem viam patefecerit.

101 V: Vat. lat. 1887, $1^{\mathrm{r}}-15^{\mathrm{v}}$ De laude ipsius; $16^{\mathrm{r}}-59^{\mathrm{v}}$ Quomodo adulator ab amico internoscatur; $60^{\mathrm{r}}-80^{\mathrm{r}}$ De cohibenda ira; $80^{\mathrm{v}}-92^{\mathrm{v}}$ Bruta animalia; 93-150 ${ }^{\mathrm{r}}$ Apophthegmata Laconica.

${ }^{102}$ A: Bibl. Angelica 1354, $1^{\mathrm{r}}-13^{\mathrm{v}}$ De laude ipsius; $13^{\mathrm{v}}-52^{\mathrm{v}}$ Quomodo adulator ab amico internoscatur; $52^{\mathrm{v}}-71^{\mathrm{r}}$ De cohibenda ira; $71^{\mathrm{v}}-82^{\mathrm{r}}$ Bruta animalia; $82^{\mathrm{r}}-135^{\mathrm{r}}$ Apophthegmata Laconica. A kézirat egyedüli említéséhez lásd Becchi: i. m. (44. jegyz.) 156, n. 5. 


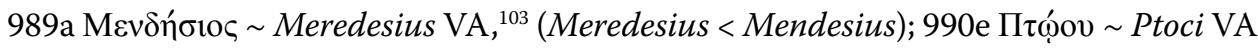

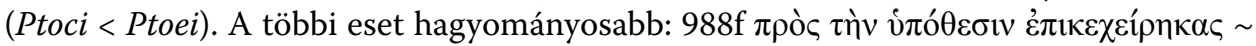
ad subiectum augmentatus es VA (augmentatus < argumentatus); 991a i $\mu \hat{i} v \sim$ nobis VA

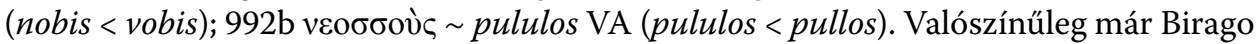
fordításából kiesett egy kisebb szövegrész, amely utólag pótolatlan maradt. Mint meg-

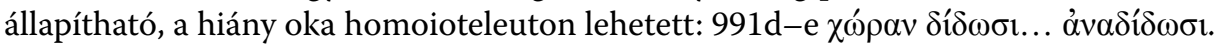

A két kódex között kevés szövegeltérés van, de ezekből határozottan az Angelica elsőbbségére következtethetünk. Ebben a szórend többször még szorosan a göröghöz

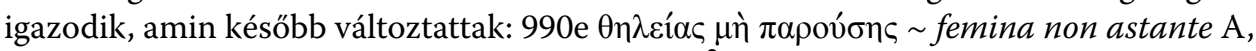

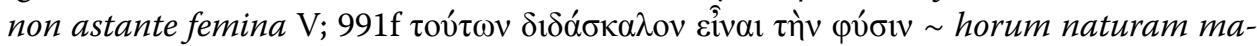
gistram esse A, magistram esse horum naturam V. Vagy az igekötő használata tükrözi

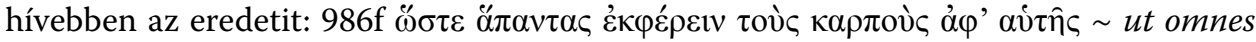

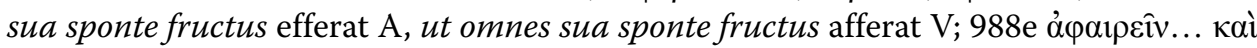

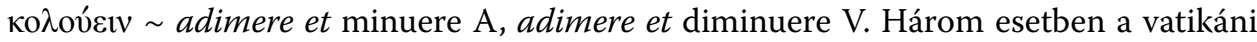
kódex utólagos javítása az Angelica-kódexben található alakot követi. Úgy tünik tehát, hogy az Angelica szövegváltozata közelebb áll Birago eredeti fordításához, még ha a vatikáni kódexet átnézték és helyenként javították is. ${ }^{104}$

Noha az egyes Moralia-darabok kiválogatását Cassarino fordítása befolyásolta, a Bruta animalia szövegének vizsgálatából az derül ki, hogy Birago a saját fordítását egy másik görög kódexcsalád alapján készítette el. Amiből dolgozott, az a П-család egyik példánya volt. A Planudés-kódexekre ( $\alpha \mathrm{AEG}$ ) elszigetelten jellemző olvasatok egész

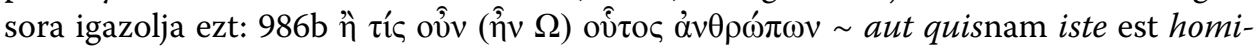

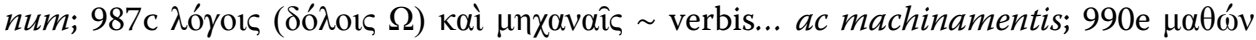

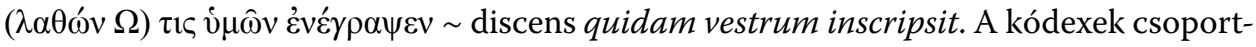
ján belül tovább szükíthetjük a kört azzal, ha olyan egyéni olvasat nyomára bukkanunk, amely csak az egyik vagy a másik szövegváltozatban található meg. Szerencsére van egy biztos ilyen szöveghely. Gryllos a rögös Ithakának a kyklópsok magától termő földjéhez való hasonlításával bizonyítja be Odysseusnak, hogy az állatok lelke, amely művelés nélkül, önmagától termi az erényt, magasabb rendű az emberekénél. Itt a többség által követett szövegben az a mondat áll, hogy a lélekkel ugyanaz a helyzet, mint a termőfölddel. Míg az EG kódexek csatlakoznak ehhez az olvasathoz, addig az $\alpha$ A kódexpár, amelynek

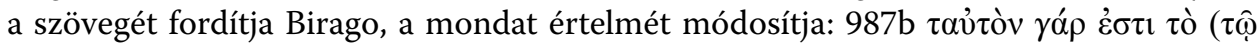

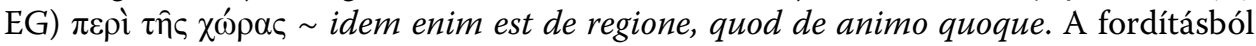
látható, hogy Birago az $\alpha \mathrm{A}$ olvasatot követte, amelyet az értelem kedvéért ki is kellett egészítenie egy tagmondattal. Nem tárgyaljuk itt most külön az EG kódexek rendhagyó eltéréseit, amelyeket Birago viszont nem követ. Helyette megpróbáljuk pontosabban meghatározni az eredeti forrást az $\alpha$ és A kódexek lehetséges eltéréseinek segítségével.

Úgy tünik, hogy az A-kódex egyedülálló olvasatai közül visszaigazolható egy

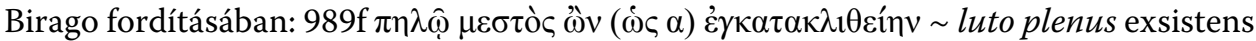

103 Vat. lat. 1887, 86 ${ }^{\mathrm{r}}$ utólag javítva Mendesius alakra.

${ }^{104}$ Maga Birago javításait feltételezi Damian: i. m. (80. jegyz.) XLI. 
inclinarem. A participium a latin fordításban arról tanúskodik, hogy a forrásszöveg az A-kódex olvasatával volt azonos. Továbblépésre azonban ezen a ponton már nincs sok lehetőség, mivel az A-kódex ${ }^{105}$ másolatainak száma igen nagy. Mint esélyes jelölt három vatikáni kódex jöhet szóba $(\beta \gamma \delta),{ }^{106}$ amelyeknek az ellenőrzése megnyugtató eredményt hozott.

Annak idején Remigio Sabbadini megpróbált kategóriákat felállítani aszerint, hogy a humanisták a fordításaikban mennyire szigorúan tartják magukat az eredeti szöveg betűjéhez, illetve engednek meg maguknak több-kevesebb szabadságot. Ebben a csoportosításban az elegáns szónoki fordítás kategóriájához képest, amelybe olyan nevek tartoznak, mint Guarino Veronese vagy Leonardo Bruni, megkülönböztette a szigorúan betű szerinti (strettamente letterale) fordítás módszerét, amelybe Francesco Filelfo és tanítványa, Lapo da Castiglionchio fordításait sorolta. ${ }^{107}$ Az ilyen felosztás nehézségeit talán nem is szükséges kiemelnünk. ${ }^{108}$ Ezt az a tény is jól mutatja, hogy az olasz tudós rövidesen változtatott álláspontján, és magát Filelfót is Guarino Veronesével, Leonardo Brunival és a többiekkel egy csoportba helyezte. ${ }^{109}$ Ma már Filelfo fordításainak alaposabb ismerete révén árnyaltabb képet tudunk alkotni a módszeréről. ${ }^{110}$ Filelfo fordításhoz való hozzáállásának a lényegét abban a meggyőződésében kereshetjük, hogy a görög eredeti értékét magasabbra emelte a latin fordításénál. Nem osztotta azt a felfogást, hogy a fordításnak az eredeti szöveggel versenyre kellene kelnie, mivel úgysem képes a nyomába érni. Ez a „hellenizáló” felfogás alapvetően eltért a kortársai többsége által vallott „latinizáló” fordításelmélettől, ami egyúttal erősebb igényt teremtett a görög eredeti tartalmainak a megragadására, némileg háttérbe szorítva a latin ékesszólás követelményeit. ${ }^{111}$ Úgy is fogalmazhatunk Marianne Pade legutóbbi osztályozását alkalmazva, hogy Filelfo a „honosító” (domesticating) módszer helyett inkább a „külföldiesí-

105 A: Par. gr. 1671.

106 ß: Vat. gr. 1013; $\gamma$ : Vat. gr. 139; $\delta$ : Vat. Reg. gr. 80.

107 R. Sabbadini: La scuola e gli studi di Guarino Guarini Veronese. Catania 1896. 134 sk. Lapo da Castiglionchio és Lampugnino Birago gyakori összekeveréséhez vö. Miglio: i. m. (80. jegyz.) 595; Damian: i. m. (80. jegyz.) VII.

${ }^{108}$ Hiszen például a fordító módszere az idők során változhat, illetve a fordítás jellege műfajok szerint eltérhet. Vö. Gualdo Rosa: i. m. (26. jegyz.) 186 skk.; Cortesi: i. m. (26. jegyz. [1995]) 148; Hankins: i. m. (29. jegyz.) 183 skk.; Berti: i. m. (26. jegyz.) 6 skk.

109 Sabbadini: i. m. (26. jegyz.) 210; uö: i. m. (65. jegyz.) 24. A közös csoport elnevezése, amelybe ezek a fordítók tartoznak, „szöveghű szónoki fordítás” (traduzione oratoria fedele).

${ }^{110}$ Lásd D. Marsh: Francesco Filelfo's Translation of the Rhetorica ad Alexandrum. In: Peripatetic Rhetoric after Aristotle. Eds. W. W. Fortenbaugh - D. C. Mirhady. New Brunswick 1994. 349 skk.; S. Fiaschi: Filelfo e 'i diritti' del traduttore. L'auctoritas dell'interprete e il problema delle attribuzioni. In: Tradurre dal greco in età umanistica. Metodi e strumenti. Ed. M. Cortesi. Firenze 2007. 85; S. Martinelli Tempesta: Platonis Euthyphron Francisco Philelfo interprete, Lysis Petro Candido Decembrio interprete. Firenze 2009. 37 skk.; J. De Keyser: Francesco Filelfo, Traduzioni da Senofonte e Plutarco: Respublica Lacedaemoniorum, Agesilaus, Lycurgus, Numa, Cyri Paedia. Alessandria 2012. Lapo da Castiglionchio hasonló kiértékeléséhez vö. C. S. Celenza: Parallel Lives: Plutarch's Lives, Lapo da Castiglionchio the Younger (1405-1438) and the Art of Italian Renaissance Translation. ICS 22 (1997) 126 skk.

111 Vö. Martinelli Tempesta: i. m. (110 jegyz.) 39 skk. 
tő" (foreignizing) fordítási eljáráshoz folyamodott, amikor előnyben részesítette a görög szöveg idegen szempontjait. ${ }^{112}$

Mindazonáltal amikor Birago fordításának a vizsgálatára kerül a sor, azt találjuk, hogy még Filelfónál is nagyobb mértékben igyekezett hű maradni a görög eredeti betűjéhez. Jól lemérhető ez a hajlam az Apophthegmata Laconica egyik találomra választott szöveghelyén, amely lehetőséget kínál számunkra Cassarino, Filelfo és Birago fordítási módszerének a párhuzamos összehasonlítására: ${ }^{113}$

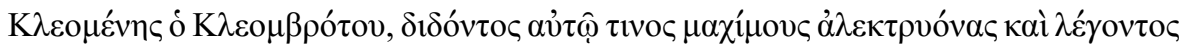

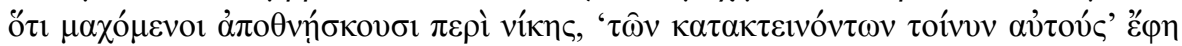

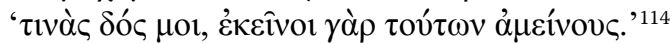

Antonio Cassarino:

Cleomenes Cleombroti, cum quidam sibi gallos pugnacissimos daret diceretque, quod pro victoria pugnantes vitam amitterent, 'Da mihi', inquit, 'aliquos ex illis a quibus isti occidentur. Illi enim sunt quam isti meliores.'

Francesco Filelfo:

Cleomenes Cleombroti filius, cum ei gallos pugnaces quis daret diceretque eos esse eiuscemodi, qui pro victoria pugnando interirent, 'Propterea', inquit, 'ex iis mihi aliquos dato, qui interimant. Illi enim sunt hisce meliores.'

\section{Lampugnino Birago:}

Cleomenes Cleombroti dante ei quodam pugnaces gallos ac dicente, quod pugnantes de victoria moriuntur, 'Da igitur', inquit, 'mihi ex occidentibus eos aliquot. Sunt enim istis meliores illi.'

A fordítások alapján inkább éreznénk rokonságot Cassarino és Filelfo, mint Filelfo és Birago stílusa között. Birago az absolutus szerkezetet (dante, dicente) és valamennyi participium coniunctumot (pugnantes, occidentibus) változatlanul lefordítja a latinban, ráadásul néhány fordulatban (de victoria moriuntur, ex occidentibus eos) kínosan pontoskodó marad. Ez a módszer teljes egészében jellemző a Bruta animalia fordítására is.

Cassarino fordításával ellentétben Birago szinte teljesen eltekint a bővítésektől és szükítésektől. Mindig pontosan annyi tagot ad meg a fordításában, amennyi az eredeti szövegben volt. Kivételt csak az olyan esetek képeznek, amikor bizonytalan egy szó jelentésében. De ekkor sem egyszerű szinonimákat állít egymás mellé, ahogy Cassarino

112 Pade: i. m. (30. jegyz.) 9.

113 Lévén ez az egyetlen olyan mü, amelyet mindhárman lefordítottak.

114 Plu. Apophth. Lac. 224b-c: „Kleomenés, Kleombrotos fia, amikor valaki harci kakasokat adott neki és azt mondta, hogy harcolás közben meghalnak a győzelemért, így felelt: »Akkor hát ezeknek a megölői közül adj nekem néhányat, mert azok jobbak ezeknél!«" 
tette, amikor a hendiadyoin eszközével élt, hanem a felsorolásban egymástól eltérő értelmezési lehetőségeket közöl, amelyek mögött más-más etimológiai értelmezések húzódnak meg. Például a nehéz értelmű görög $\alpha \pi \varepsilon ı р о к \alpha \lambda i ́ \alpha$ szó esetében két etimológiai

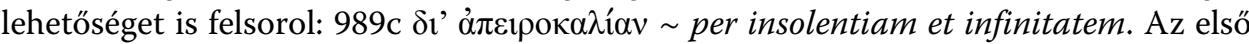

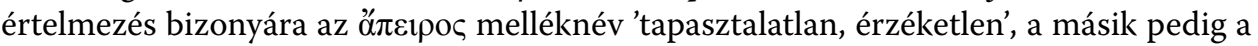
'végtelen' értelmén alapul. Hasonlóan jár el egy másik esetben, bár ott inkább két olvasat

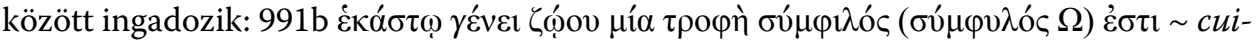
que generi animalium unum cognatum amicumque est alimentum. Az eltérő olvasatot feltehetően nem a saját szemével látta a kéziratban, hanem ösztönösen ráérzett, vagy pedig az $\mathrm{l} / \mathrm{v}$ ejtésének azonossága alapján írnoki hibát sejtett.

Kihagyásokra csupán egy-egy rövid szónál bukkanunk ( $\pi \mathrm{o} \lambda \hat{v}, \mu \hat{\alpha} \lambda \lambda \mathrm{ov}, \alpha_{\varepsilon} \varepsilon_{1}, \kappa \alpha i ̀ v v \hat{v}$, $\pi \omega \varsigma$ ), amelyeket elenyésző számuk miatt inkább a véletlennek tulajdoníthatunk. Az arányok érzékeltetésére megjegyezhetjük, hogy míg Cassarinónál a névszók és igék nem szó szerinti fordítását harminc-harminc alkalommal állapítottuk meg, addig Birago esetében ez a szám nem haladja meg az ötöt-ötöt.

A mondatszerkesztés és a stílus néhány különbsége szembeötlö. A klasszikus latin gyakorlatát követve Cassarino jóval nagyobb számban használ az alárendelt mellékmondatokban coniunctivust, mint Birago. Különösen érvényes ez a praesens perfectum coniunctivus és a futurum perfectum gyakoriságára. Meglepő, hogy Birago a középkori nyelvhasználatot követve az ipse névmást legalább húsz esetben mutató névmási szerepben használja.

Ami a választékosságot illeti, Biragónál az okadó үớp egységesen az enim, a $\delta \varepsilon$ kötőszó pedig az autem fordításban jelenik meg. Cassarino viszont, aki mint láttuk, a koí fordításában is szívesen váltogatja az et, ac / atque és aut kötőszavakat, hasonló változatosságra törekszik, amikor felváltva használja a nam / enim fordításokat. Szinte csak Cassarinónál fordulnak elő, méghozzá ismétlődően, az itaque, scilicet, haud, valamint a nequaquam és verum szavak, ezzel szemben Birago nyelvére korlátozódik az utique határozószó.

A participium coniunctum mellékmondattal való visszaadása helyett, ami Cassarino gyakorlatára jellemző, Birago az esetek többségében hajlik arra, hogy inkább tükörfordítást adjon. Ezzel a latin mondatot a görög szerkezet felé tolja el. Meghökkentő módon még a görög létige ڤ̋v participiumát is átmenti, ahol lehet, a sután hangzó latin exsistens behelyettesítésével. ${ }^{115}$ Azon a ponton, ahol Gryllos a vágyak osztályozásába fog, néhány sor kiválóan tükrözi ezt a jelenséget, ezért párhuzamosan közöljük Cassarino és Birago szövegét:

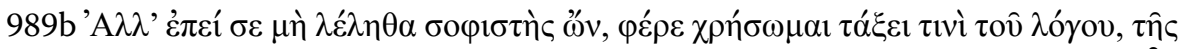

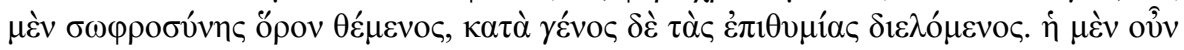

115 Köztudott, hogy a latin nyelvben a létige participiuma (vö. absens, absentis) nem képezhető. 


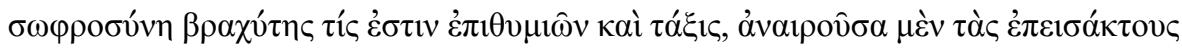

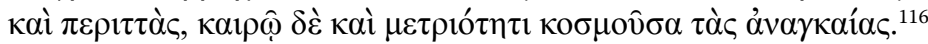

Sed quando tibi rhetor sum visus, age orationi ordinem quendam adhibebo, et cum temperantiam definiam, cum libinides atque appetentias in genera distribuam. Est igitur temperantia moderatio et contractio quaedam libidinum, quae vanas ac superfluas incidit, necessarias mensura et tempore moderatur.

Sed quando quidem te non latui sophista exsistens, age utar quodam ordine orationis, ponens fines continentiae, perque genera cupiditates distinguens. Est igitur continentia brevitas quaedam cupiditatum et ordo, interimens quidem introductas ac superfluas cupiditates, tempore autem et moderamine ornans necessarias.

Azoknak a jelenségeknek a többségét, amelyeket Cassarino és Birago fordítási módszerével kapcsolatban eddig tárgyaltunk, összesürítve megtaláljuk egy rövid idézetben. A korábban már érintett szöveghelyen Gryllos annak az okát adja meg, hogy az állatok bátorsága miért magasabb rendü:

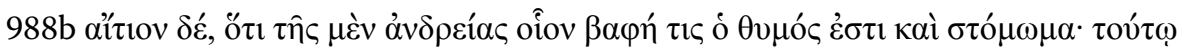

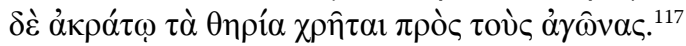

Causa autem est, quod naturali illo impetu animi, quem animalia in proeliis acrem, vehementem indomitumque afferunt, fortitudo plurimum iuvatur atque excitatur.

Causa autem est, quia fortitudinis quasi intinctio et ferruminatio quaedam est animus, hoc autem mero utuntur ferae ad certamina.

Cassarino bővítései a platóni $\theta 0 \mu$ ó c magyarázatára (naturali illo impetu animi) és a keveretlenség tulajdonságára (acrem, vehementem indomitumque) egyaránt kiterjednek, azonkívül az alanyi és tárgyi szempontokat is megfordítja, amikor az indulat megedzésének és élének a képét passzív igealakokkal (iuvatur atque excitatur) írja körül. ${ }^{118}$ Birago fordítása ezzel szemben szorosan követi a görög eredetit, semmit nem ad hozzá, sem el nem vesz belőle, annak a kockázata mellett is, hogy a túlzott pontossággal a megértést áldozza fel.

116 „De mivel nem maradt rejtve előtted, hogy szofista vagyok, nosza, hadd éljek a beszédben némi rendszerezéssel azáltal, hogy a mértékletességnek a meghatározását adom, a vágyakat pedig a fajtáik szerint osztályozom. A mértékletesség tehát a vágyaknak valamiféle leszükítése és szabályozása, amely a kívülről jött és felesleges vágyakat eltávolítja, a szükséges vágyakat pedig az alkalom és a mérték szerint elrendezi.”

117 „Ennek pedig az az oka, hogy a bátorságnak mintegy megedzése és éle az indulat, ezzel pedig az állatok vegyítetlenül élnek a küzdelmeikben."

118 A bátorság megedzése vagy megélezése eredetileg genitivus obiectivus kapcsolat. 
Tanulmányunk befejező részében a szóhasználat kérdésére óhajtunk kitérni. Ezzel kapcsolatban fontos leszögeznünk, hogy Cassarino és Birago fordítása jelentősen eltér. Míg Cassarino a görög szavakat általában „értelem szerint” fordítja, és nem törekszik arra, hogy egy adott szót mindig ugyanazzal a latin megfelelővel adjon vissza, ${ }^{119}$ addig Birago szinte mindig „szó szerint” ugyanazokat a latin szavakat választja egy adott görög szó megfelelőjéül. Ennek a jelenségnek a magyarázatát nyilván abban találjuk, hogy a két fordító más-más módon sajátította el a görög nyelvet. Cassarino csaknem fél évtizedet töltött Konstantinápoly élő nyelvi közegében, ott tanulta meg a nyelvet bizánci mesterektől, Birago viszont feltehetően azoknak a szótáraknak a segítségével alakította ki a szókészletét, amelyek a saját korában és a személyes kapcsolatai révén elérhetők voltak. A szóválasztások kérdését kétféle szempontból vizsgáljuk meg. Egyrészt arra a kérdésre keressük a választ, hogy Birago szóhasználatában találunk-e Cassarino befolyására utaló jeleket. Másrészt pedig Birago lexikális alapú fordításából megpróbáljuk az általa használt szótárak különböző rétegeit elkülöníteni.

Egy-két szöveghelyből gyanú ébred arra vonatkozóan, hogy Birago csakugyan olvasta Cassarino fordítását. A П-család kódexeiben az egyik helyen, ahol Odysseus azt mondja Kirkének, hogy a szavaival újabb bájitalt kever és kotyvaszt, a második ige hiányzik. Ennek ellenére Birago ezt az igét is lefordítja nagyon hasonlóan Cassarinóhoz:

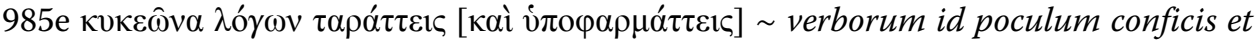
commisces Cass., istam veneficam sermonum potionem agitas ac permisces Bir. Annak ismeretében, hogy Birago sohasem folyamodik bővítésekhez, illetve máshol nem követi a Planudés-kódexeken kívül eső olvasatokat, Cassarino szövegének tudat alatti átszivárgására gyanakodhatunk. Ugyanezt feltételezhetjük egy másik esetben, ahol Birago fordítása a Cassarino által használt g-kódex elszigetelt olvasatát tükrözi: 986d $\eta \mu \hat{\alpha} \varsigma \tau \varepsilon \pi \varepsilon i ́ \theta \varepsilon 1 \varsigma$,

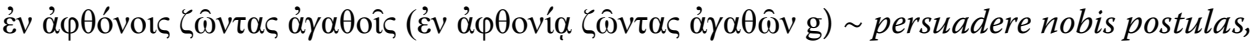
ut qui vitam omni bonorum copia plenam ducimus Cass., nobisque suades in copia bonorum viventibus Bir. Ismét nem volna meghatározó ez a különbség, ha máshol Birago nem követné szigorúan az eredeti szerkezetet. Két további hiba, amelyet Birago láthatóan átvett Cassarinótól, megerősíti a feltevésünket. Az egyikben Cassarino véletlenül a perfectum helyett imperfectum igealakot fordít, amit Birago is követ: 990b $\delta 1 \varepsilon \varphi \theta \alpha \rho \kappa \varepsilon v$

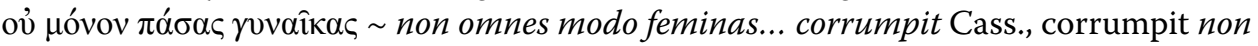
modo feminas Bir. A másik esetben látványosabb hibáról van szó, amely Cassarino laza fordítási kísérletéből ered. Birago némi módosítással csatlakozik ehhez: 986c $\tau$ í $\beta o v ́ \lambda \varepsilon 1$ $\varepsilon \rho \omega \tau \hat{\alpha} v ;$ roga, quid vis? Cass., quid vis, interroga! Bir. A görög $\varepsilon \rho \omega \tau \hat{\alpha} v$ infinitivus alakot

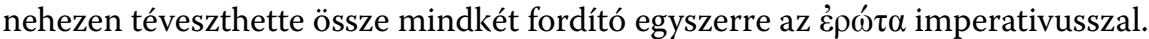

Természetesen Birago fordítása az esetek túlnyomó többségében a maga útján halad anélkül, hogy Cassarino befolyásának a nyomát észrevennénk. Ám ezzel együtt is húsz-harminc esetben a közös szóválasztás, amely gyakran szópárokra vagy szókapcsolatokra is kiterjed, belső összefüggésről árulkodik. Beérjük egyetlen példa említésével. Amikor Gryllos elmondja, hogy Agamemnón egy kiváló versenykancát kapott a sikyóni

119 Ehhez a jellegzetességhez a platóni Respublica fordításában vö. Hankins: i. m. (17. jegyz.) 422 skk. 
férfitól cserébe azért, hogy ne kelljen hadba vonulnia, az itt használt görög kifejezést

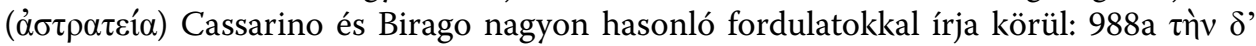

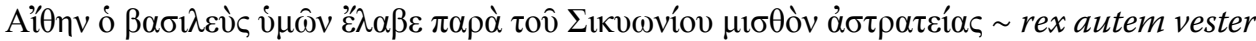
a Sicyonio Aethen pretium, quo is a militia vacaret, acceperit Cass., Aethem autem rex vester sumpsit a Sicyonio pretium vacationis militiae Bir. Azt sem szabad elfelejteni, hogy Birago már az öt Moralia-mű kiválasztásában és sorrendjében is Cassarinót követi.

A XV. századi görög-latin szótárak történetében mérföldkövet jelentett az 1431-ben összehívott bázeli zsinat, ahová Nicolaus Cusanus, a későbbi bíboros magával vitte az alexandriai Kyrillosnak tulajdonított, késő ókori szótár egyik kéziratát. ${ }^{120} \mathrm{Ez}$ a kézirat rövid időn belül további másolatok forrásává vált, amelyek közül több is a kiegészítések és lapszéljegyzetek sokaságával tanúsítja, hogy a szótár nagy népszerűségnek örvendett a humanisták körében. ${ }^{121}$ Nyomtatott formában Stephanus is megjelentette a következő évszázadban, ${ }^{122}$ modern szövegkiadása pedig a XIX. században készült el. ${ }^{123}$ Ugyanakkor már az 1420-as évektől formálódni kezdett a szótáraknak egy másik nagy ága, amely a humanisták által olvasott ókori szerzők szóanyagára épült. Előbb-utóbb ez a szótári ág több különböző forrást is magába olvasztott, és egy bonyolult, de többé-kevésbé egységes szótárcsoporttá alakult, amelyet Peter Thiermann nyomán Guarino Veronese szótárának nevezhetünk. ${ }^{124} \mathrm{Ez}$ a nagy szótárcsoport, amelynek négy összeszerkesztési fokát $(\mathrm{a}-\mathrm{d})$ különíthetjük el, ${ }^{125}$ végül elvezetett a Giovanni Crastone által összeállított és 1478-ban nyomtatásban megjelent görög-latin szótárhoz. ${ }^{126}$

Birago Moralia-fordításai biztosan megelőzték Crastone szótárának a megjelenését, ezért közvetlenül ebből a szótárból nem dolgozhatott. Viszont a köztes szótárcsoport egyik vagy másik összeszerkesztési fokához hozzáférhetett, és természetesen használhatta Pseudo-Kyrillos szótárát is. Amikor tehát a szókészlet vizsgálatába fogunk, akkor olyan eseteket érdemes keresnünk, amelyek a jelentés egyéni megválasztása alap-

${ }^{120}$ British Library, Harl. 5792.

${ }^{121}$ P. Thiermann: I dizionari greco-latini fra medioevo e umanesimo. In: Les manuscrits des lexiques et glossaires de l'Antiquité tardive à la fin du Moyen Âge. Ed. J. Hamesse. Turnhout 1996. 659 sk.; P. Botley: Learning Greek in Western Europe, 1396-1529. Grammars, Lexica, and Classroom Texts. Philadelphia 2010. 63. Egy-egy ilyen másolat (Vind. Suppl. gr. 45; Scor. $\Sigma$ I.12) részletes elemzéséhez legutóbb vö. Zs. Ötvös: „Janus Pannonius's Vocabularium”. The Complex Analysis of the Ms. ÖNB Suppl. Gr. 45. Budapest 2015. 107 skk.; Bolonyai G.: Benedictus és szótára. AntTan 61 (2017) 71 skk.

${ }^{122}$ Glossaria duo e situ vetustatis eruta, ad utriusque linguae cognitionem et locupletationem perutilia. Lexicon graecolatinum vetus, in calce quorundam Cyrilli scriptorum inventum. Anno MDLXXIII, excudebat Henr. Stephanus, 363-666.

${ }^{123}$ G. Goetz - G. Gundermann: Glossae Latinograecae et Graecolatinae. Leipzig 1888. 213 skk.

${ }^{124}$ P. Thiermann: Das Wörterbuch der Humanisten. Die griechisch-lateinische Lexikographie des fünfzehnten Jahrhunderts und das 'Dictionarium Crastoni'. Diss. Hamburg 1994; uö: i. m. (121. jegyz.) 657 skk.; Botley: i. m. (121. jegyz.) 64 sk.; A. Rollo: Study Tools in the Humanist Greek School: Preliminary Observations on Greek-Latin Lexica. In: Teachers, Students, and Schools of Greek in the Renaissance. Eds. F. Ciccolella - L. Silvano. Leiden 2017. $26 \mathrm{skk}$.

125 Thiermann: i. m. (124. jegyz. [1994]) 68 skk.; Rollo: i. m. (124. jegyz.) 28 skk.

126 Dictionarium graecum cum interpretatione latina [Milano, 1478]. 
ján leszűkítik a lehetőséget az egyik vagy a másik szótár használatára. Az adatok visszaellenőrzéséhez Pseudo-Kyrillos és Crastone teljes szótára mellett a Guarino-féle szótárcsoport több összeszerkesztési fokából használunk fel kéziratokat. ${ }^{127}$

A jelentésmeghatározások egy részénél Birago egyértelműen csak Pseudo-Kyrillos szótárához folyamodott. Azokat a példákat tekinthetjük bizonyító erejünek, ahol a Birago által megadott jelentés vagy nem egyezik meg semelyik másik szótár jelentésével, vagy pedig már maga a címszó sem található meg ezekben. A főnevekből, mellékne-

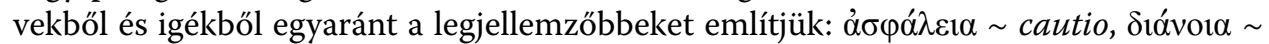

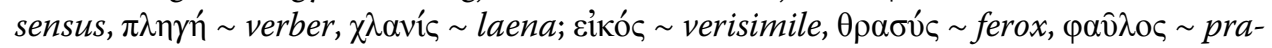

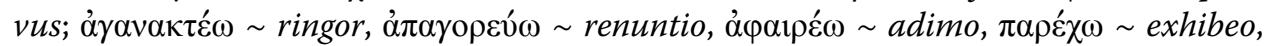
$\sigma \pi \varepsilon v ́ \delta \omega \sim$ propero.

A Pseudo-Kyrillos használata még jobban megmutatkozik azokban az esetekben, amikor Birago a szótárban található rokon alakokból képezte ki a jelentéseket a pontos

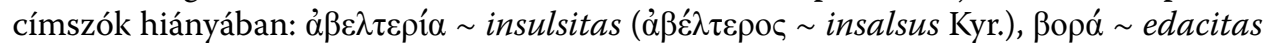

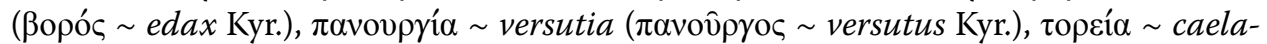
tura (

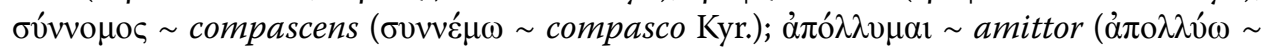
amitto Kyr.).

Nehéz azokról az előfordulásokról dönteni, amelyekben a Birago által megadott jelentés egyaránt megtalálható Pseudo-Kyrillos szótárában, illetve a köztes szótárcsoportban és/vagy Crastone szótárában is. Ezekben az esetekben Birago forrása ugyanúgy lehetett az egyik vagy a másik. Jobban mondva kivételt csak azokkal az esetekkel tehetünk, amelyekben az egyezés a Pseudo-Kyrillos és Crastone között áll fenn. Vélhetően ugyanis a nyomtatott szótár több jelentést átvett Pseudo-Kyrillostól. ${ }^{128}$ Ismét közlünk

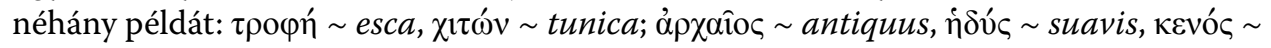

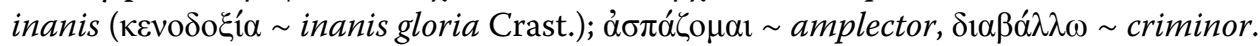

Arra a kérdésre, hogy vajon Birago használta-e a Crastone szótárának összeállításához vezető köztes szótárcsoportot, határozott igennel kell felelnünk. Nagy számban találunk olyan jelentéseket, amelyek a Pseudo-Kyrillosból hiányoznak, ám megvannak ennek a szótárcsoportnak egy vagy több tagjánál. A szótári jelentéshez szorosan ragaszkodó fordítások nyomra vezethetnek. Különös például, hogy amikor arról beszél a szöveg, hogy a Sphinx rejtvényeket és talányokat sző, miért fordítja Birago a felso-

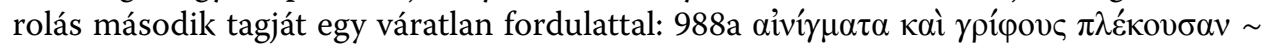
aenigmataque et insolubilia nectentem. A magyarázatot az $\mathrm{N}^{5}, \mathrm{~L}^{1}, \mathrm{~V}^{10}$ és $\mathrm{B}^{1}$ kódexek közös hagyománya adja meg: $\gamma$ pí következetlen, ha arra gondolt, hogy a Sphinx valami kibogozhatatlant sző. Egy má-

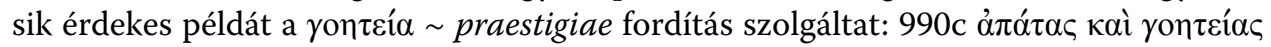

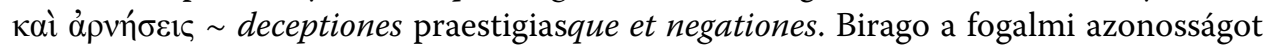

${ }_{127} \mathrm{~N}^{5}$ : Marston 94 (a); L ${ }^{2}$ : Harl. 6313 (b); L ${ }^{1}$ : Add. 14083; $\mathrm{V}^{10}$ : Vat. Urb. gr. 162 (c); B ${ }^{1}$ : Bibl. Univ. Bologna 2498 (d).

128 Vö. Botley: i. m. (121. jegyz.) 65. 


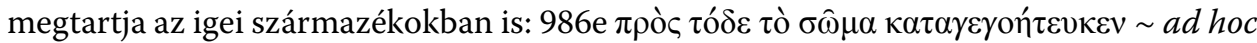

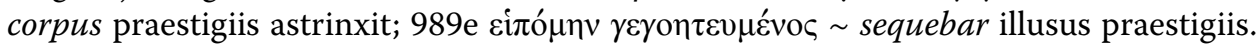

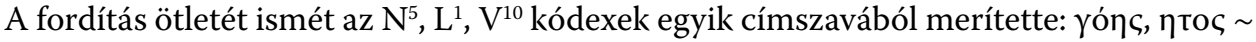
praestigiator. ${ }^{129}$ Mivel pedig látta, hogy a főnévi és igei alakok ebből a tőből képződnek, úgy vélte, hogy ezt a fordításban is mindvégig meg kell őriznie. Egy harmadik példát az a szöveghely nyújt, amelyben arról van szó, hogy az állatoknál a természet a testi erő

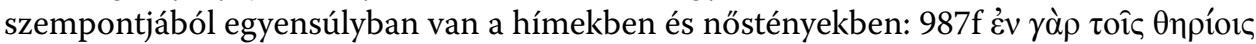

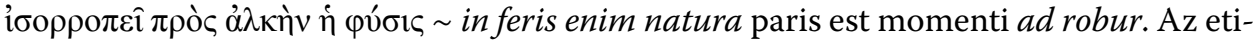

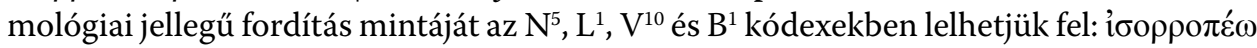
$\sim$ sum aequalis momenti.

Mindezek a jelentések a köztes szótárcsoportból Crastone szótárába is beépültek. A jelentős számú további példa közül csak néhányat sorolunk fel: à á́

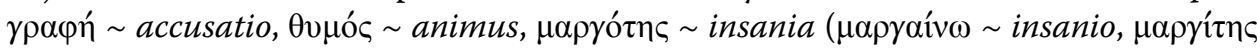

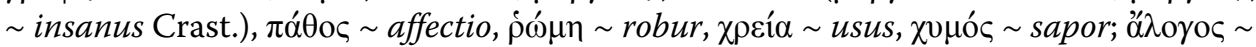

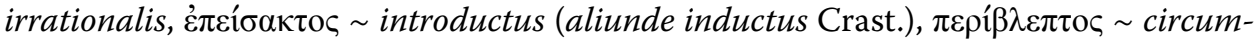

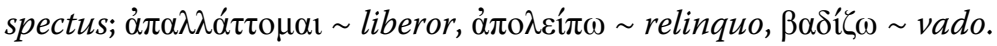

A vizsgálat eredménye tehát két irányba mutat. Birago egyfelől biztosan használta Pseudo-Kyrillos hagyományos szótárát, amelyből a jelentésmeghatározások egy részét nyerte. Másfelől igen jelentős mértékben folyamodott a köztes szótárcsoport tagjaihoz is, amivel a Crastone szótárával való nagyfokú egyezések is magyarázhatók. A szótári anyagnak ez a kettős felhasználása nem tűnik egyedülállónak Birago korában. Több kézirat is tanúskodik arról, hogy a két szótári hagyományt próbálták ötvözni, akár úgy, hogy a Pseudo-Kyrillos címszavait egészítették ki a Guarino-féle szótárcsoport anyagával, ${ }^{130}$ akár úgy, hogy ennek a szótárcsoportnak a kódexeire vezettek fel címszavakat a Pseudo-Kyrillosból kisebb-nagyobb számban. ${ }^{131}$ Magának Crastone szótárának a kezdeti lapjain is felfedezhetők címszavak Pseudo-Kyrillos szótárából, ami fényt vethet a szótár összeállításának korábbi szakaszára. Mindenesetre a nyomtatott szótár Milánóban jelent meg, és feltehetően itt folytak az előmunkálatok is. Bár a köztes szótárcsoport fő elterjedési helyéül Firenzét állapították meg az 1440-1490 közötti években, ${ }^{132}$ egy kódexről tudunk, amelyet Kónstantinos Laskaris használt a tanítványaival Milánóban az 1460-as évek közepén. ${ }^{133}$ Bizonyára nem véletlen, hogy éppen ebben a kódexben találhatók a Pseudo-Kyrillos címszavaiból a legterjedelmesebb bejegyzések. Egyébként Crastone szótárának előszavában azt olvassuk, hogy a szerző nem tett mást, mint hogy kijavította és gondozásba vette, amit Kónstantinos Laskaris és mások kevésbé szépen és jól állítottak össze. ${ }^{134}$ Laskaris és tanítványainak a kódexe egy köztes másolaton keresz-

$129 \mathrm{Az} \mathrm{L} \mathrm{L}^{2}$ és $\mathrm{B}^{1}$ kódexek nem adják meg ezt a jelentést.

${ }^{130}$ Például Vind. Suppl. gr. 45.

$131 \mathrm{~V}^{4}$ : Vat. gr. 2355; V ${ }^{10}$ : Vat. Urb. gr. 162; Vª Vat. gr. 2339. Vö. Thiermann: i. m. (121. jegyz.) 674 sk.; Botley: i. m. (121. jegyz.) 65.

132 Botley: i. m. (121. jegyz.) 64; Rollo: i. m. (124. jegyz.) 36 sk.

$133 \mathrm{~V}^{4}$ : Vat. gr. 2355.

134 Vö. L. Gualdo Rosa: Crastone, Giovanni. DBI 30 (1984) 578 skk. 
tül abból a kéziratból származik, amelyet hosszú ideig Francesco Filelfónak tulajdonítottak. ${ }^{135}$ Ezt a kapcsolatot ugyan ma már cáfolják, ám annyi bizonyos, hogy a Guarinoféle szótárcsoport egyik kézirati ága eljutott Milánóba, ahol a szótárat az 1460-as évek közepén nyelvtanulás céljára használták. Az időpont egybeesik azzal, amikor Birago a Moralia-műveket elkezdte fordítani. Nem mellékes tény, hogy maga Birago és Pier Candido Decembrio is egy-két évvel korábban csatlakozott ahhoz a folyamodványhoz, amely Laskaris görögtanárrá való állami kinevezését szorgalmazta. ${ }^{136}$

Mindezek alapján feltételezhető, hogy Birago a milánói kapcsolatrendszerén keresztül jutott hozzá az újnak számító szótáregyütteshez. Korábbi tudását, amely PseudoKyrillos szótárán alapult, idővel kiegészítette a pontosabb és szélesebb feldolgozottságra épülő jelentésekkel. A fordításában kimutatható szótári rétegek valószínűleg azokat az állomásokat tükrözik, amelyeken a görög szókincsének bővítése során átesett.

SUMMARY

Plutarch's lively dialogue Bruta animalia ratione uti was translated in the course of the 15th century by three different persons whose works are only extant in manuscripts. For establishing the connections between these translations a thorough study of the texts of the codices is needed. In a previous article, we have dealt with Giovanni Regio's translation, which is the latest in time (1488), and found traces of the latter's dependence from the translation of the Milanese Lampugnino Birago (c. 1465-1470). The aim of the present paper is to inquire into the text of the earliest translation by the Sicilian Antonio Cassarino (c. 1440-1445) in parallel with the text of Lampugnino Birago's translation which followed it after two and a half decades. The different translation methods and devices used by the translators provide ample space for comparison. Whereas Cassarino's approach is more in keeping with the humanist ideal of 'translation by sense' (ad sententiam), Birago as a rule follows a principle of 'translation by word' (ad verbum), keeping close to the letter. Beyond the questions of translation theory in general problems relating to the textual tradition of the Latin codices, the possible Greek sources of the translations, and number of lexical matters are discussed.

Keywords: Plutarch, Bruta animalia ratione uti, Antonio Cassarino, Lampugnino Birago, humanist Latin translations, ad sententiam and ad verbum translation methods

GAÁL BALÁZS

ELTE Bölcsészettudományi Kar

mithuna@t-online.hu

A cikk a Creative Commons Attribution 4.0 International License (https://creativecommons.org/ licenses/by/4.0) feltételei szerint publikált Open Access közlemény, melynek szellemében a cikk bármilyen médiumban szabadon felhasználható, megosztható és újraközölhető, feltéve, hogy az eredeti szerző és a közlés helye, illetve a CC License linkje és az esetlegesen végrehajtott módosítások feltüntetésre kerülnek. (SID_1) $36 \mathrm{sk}$.

${ }^{135}$ F$^{1}$ : Laur. Conv. Soppr. 181. Vö. Thiermann: i. m. (124. jegyz. [1994]) 104; Rollo: i. m. (124. jegyz.)

${ }^{136}$ Damian: i. m. (80. jegyz.) XXXIII. 